Geomicrobiology Journal

\title{
Activity, Distribution, and Diversity of Sulfate Reducers and Other Bacteria in Sediments above Gas Hydrate (Cascadia Margin, Oregon)
}

Katrin Knittel , Antje Boetius , Andreas Lemke, Heike Eilers , Karin Lochte, Olaf Pfannkuche, Peter Linke \& Rudolf Amann

To cite this article: Katrin Knittel, Antje Boetius , Andreas Lemke, Heike Eilers, Karin Lochte , Olaf Pfannkuche, Peter Linke \& Rudolf Amann (2003) Activity, Distribution, and Diversity of Sulfate Reducers and Other Bacteria in Sediments above Gas Hydrate (Cascadia Margin, Oregon), Geomicrobiology Journal, 20:4, 269-294, DOI: 10.1080/01490450303896

To link to this article: https://doi.org/10.1080/01490450303896

曲 Published online: 10 Nov 2010.

Submit your article to this journal $\pi$

Џll Article views: 366

Q View related articles $\sqsubset$

Citing articles: 202 View citing articles $\longleftarrow$ 


\title{
Activity, Distribution, and Diversity of Sulfate Reducers and Other Bacteria in Sediments above Gas Hydrate (Cascadia Margin, Oregon)
}

\author{
KATRIN KNITTEL \\ Max Planck Institute for Marine Microbiology \\ Bremen, Germany
}

\begin{abstract}
ANTJE BOETIUS
Alfred Wegener Institute for Polar and Marine Research

Bremerhaven, Germany

International University Bremen

Bremen, Germany and Max Planck Institute for Marine Microbiology

Bremen, Germany
\end{abstract}

\section{ANDREAS LEMKE HEIKE EILERS}

Max Planck Institute for Marine Microbiology

Bremen, Germany

\section{KARIN LOCHTE}

Institut für Meereskunde an der Universität Kiel

Kiel, Germany

\section{OLAF PFANNKUCHE PETER LINKE}

GEOMAR Research Center for Marine Geosciences

Kiel, Germany

Received 11 February 2003; accepted 7 April 2003.

We thank the officers, crew, and shipboard scientific party for excellent support during RV SONNE cruises SO143 and SO148. Tina Treude helped with sampling on board, Julia Polansky is acknowledged for assistance with FISH, Sabine Schäfer for total cell counts, Tina Lösekann and Heiko Löbner for sulfate reduction rates, Doris Setzkorn for thymidine incorporation, and Dirk Rickert for sulfate and porosity data. We thank Beth Orcutt and the two reviewers for their extremely helpful comments on the manuscript. This study was part of the programs MUMM (Mikrobielle UMsatzraten von Methan in gashydrathaltigen Sedimenten, 03G0554A) and TECFLUX I and II (TECtonically induced FLUXes, 03G0148A) supported by the Bundesministerium für Bildung und Forschung (BMBF, Germany). Further support was provided from the Max-Planck Society, Germany. This is publication GEOTECH-17 of the program GEOTECHNOLOGIEN of the BMBF and the Deutsche Forschungsgemeinschaft (Germany).

Address correspondence to Katrin Knittel, Max Planck Institute for Marine Microbiology, Department of Molecular Ecology, Celsiusstrasse 1, 28359 Bremen, Germany. E-mail: kknittel@mpi-bremen.de 


\title{
RUDOLF AMANN
}

\author{
Max Planck Institute for Marine Microbiology \\ Bremen, Germany
}

\begin{abstract}
Cold seep environments such as sediments above outcropping hydrate at Hydrate Ridge (Cascadia margin off Oregon) are characterized by methane venting, high sulfide fluxes caused by the anaerobic oxidation of methane, and the presence of chemosynthetic communities. Recent investigations showed that another characteristic feature of cold seeps is the occurrence of methanotrophic archaea, which can be identified by specific biomarker lipids and 16S rDNA analysis. This investigation deals with the diversity and distribution of sulfate-reducing bacteria, some of which are directly involved in the anaerobic oxidation of methane as syntrophic partners of the methanotrophic archaea. The composition and activity of the microbial communities at methane vented and nonvented sediments are compared by quantitative methods including total cell counts, fluorescence in situ hybridization (FISH), bacterial production, enzyme activity, and sulfate reduction rates. Bacteria involved in the degradation of particulate organic carbon (POC) are as active and diverse as at other productive margin sites of similar water depths. The availability of methane supports a two orders of magnitude higher microbial biomass (up to $9.6 \times 10^{10} \mathrm{cells} \mathrm{cm}^{-3}$ ) and sulfate reduction rates (up to $8 \mu \mathrm{mol} \mathrm{cm}^{-3} \mathrm{~d}^{-1}$ ) in hydrate-bearing sediments, as well as a high bacterial diversity, especially in the group of $\delta$-proteobacteria including members of the branches Desulfosarcina/Desulfococcus, Desulforhopalus, Desulfobulbus, and Desulfocapsa. Most of the diversity of sulfatereducing bacteria in hydrate-bearing sediments comprises seep-endemic clades, which share only low similarities with previously cultured bacteria.
\end{abstract}

Keywords anaerobic oxidation of methane, sulfate reduction, sulfate-reducing bacteria, bacterial production, extracellular enzymes, syntrophic consortia, bacterial diversity, gas hydrate, Hydrate Ridge, Cascadia margin

\section{Introduction}

The greenhouse gas methane is present in huge amounts in marine sediments and exists either as crystalline, solid phase methane hydrates, or as free gas. Methane emission to the hydrosphere is controlled by a microbial process called anaerobic oxidation of methane $(\mathrm{AOM})$, which involves methane as electron donor and sulfate as electron acceptor (Hinrichs and Boetius 2002, and references therein) and which removes most methane within the sediments (Reeburgh 1996). The metabolic process of AOM is assumed to be a reversal of methane formation involving methanogenic archaea and sulfate-reducing bacteria as partners (Hoehler et al. 1994; Valentine and Reeburgh 2000). Recent studies have demonstrated that AOM is mediated by a structured consortium of archaea belonging to the order Methanosarcinales (ANME-2 group), and SRB of the Desulfosarcina/Desulfococcus branch of the $\delta$-proteobacteria (Boetius et al. 2000a; Orphan et al. 2001b), in the following referred to as "ANME-2/DSS aggregates." These consortia oxidize methane with equimolar amounts of sulfate, yielding carbonate and sulfide, respectively (Nauhaus et al. 2002). A second archaeal group (ANME-1), distantly related to Methanosarcinales, has also been shown to mediate AOM (Michaelis et al. 2002; Orphan et al. 2002). Neither ANME-1 nor ANME-2 or their sulfate-reducing partners have been isolated yet and the enzymes and biochemical pathways involved in AOM remain unknown.

This investigation was carried out to quantify microbial activity and distribution at a cold seep environment and to analyze its community composition. At Hydrate Ridge, discrete methane hydrate layers occur at the seafloor, at a water depth of 600-800 m corresponding to the hydrate stability limit (Suess et al. 1999). The hydrates are located a few centimeters beneath the sediment surface and form mounds of several meters in diameter 
(Suess et al. 2002). The mounds are covered by sediment and populated by thick mats of the sulfur-oxidizing filamentous bacteria Beggiatoa (Sahling et al. 2002; Torres et al. 2002). Another typical chemosynthetic community of Hydrate Ridge is the vesicomyid clams of Calyptogena forming clam fields of several meters diameter. Both, Beggiatoa and Calyptogena spp., are indicative of active methane seeping (Tryon et al. 2002). A third community is formed by the subsurface dwelling bivalves Acharax, which occur farther away from the strongly methane-vented sites and are here referred to as reference sites. The distribution of chemosynthetic communities at Hydrate Ridge is mainly related to the sulfide flux from the surface sediments (Sahling et al. 2002), which is caused by methane-dependent sulfate reduction (Nauhaus et al. 2002). As a consequence, AOM and sulfate reduction rates (SRR) correlate strongly across the different samples and even within the sediment profile at Hydrate Ridge (Treude et al. submitted). The hydrate-bearing sediments of Hydrate Ridge show high rates of methane-dependent sulfate reduction and harbor extremely high amounts of AOM mediating ANME-2/DSS aggregate biomass (Boetius et al. 2000a).

This study focused on quantification and comparison of abundance, activity, and diversity of microbial organisms involved in carbon cycling at methane-vented and methanedepleted sites (Beggiatoa and Calyptogena sites vs. Acharax reference). Earlier investigations showed a relatively low diversity of archaea in cold seep sediments compared to the bacterial diversity in these habitats (Hinrichs et al. 1999; Lanoil et al. 2001; Orphan et al. 2001a, 2002; Teske et al. 2002), despite their quantitative dominance at cold seeps (Boetius et al. 2000a; Michaelis et al. 2002). This study addressed the bacterial diversity and abundance in sediments above gas hydrate, especially regarding the SRB community structure.

\section{Materials and Methods}

\section{Study Site and Sampling}

Sediment samples were obtained during RV SONNE cruises SO143-2 in August 1999 (Bohrmann et al. 2000) and SO148-1 in August 2000 (Linke and Suess 2001) at the crest of southern Hydrate Ridge $\left(44^{\circ} 34^{\prime} \mathrm{N}, 125^{\circ} 09^{\prime} \mathrm{W}, 780 \mathrm{~m}\right.$ water depth) at the Cascadia convergent margin off the coast of Oregon. Sediment cores of 20-40 cm length were obtained using a video-guided multiple corer from gas hydrate bearing sediments and from reference sites not enriched in methane in the surface sediments (Table 1). Sediments from above hydrate were covered by mats of filamentous sulfur-oxidizing bacteria of the genus Beggiatoa (stations 105-1 and 19-2; called "Beggiatoa mats") or by clam fields of Calyptogena spp. (stations 185-1 and 38-1; called "Calyptogena fields").

\section{Geochemical Description of the Study Sites}

Sediments from both sites, Beggiatoa mats and Calyptogena fields, were highly sulfidic and gassy. Oxygen had a maximum penetration of a few millimeters. Sulfide concentrations of up to $28 \mathrm{mM}$ were reached within 3-5 cm depth in the Beggiatoa mats with concurrent depletion of sulfate down to $<2 \mathrm{mM}$. In Calyptogena fields sulfate penetrated deeper into the sediments due to the bioturbating activity of the clams. Nevertheless, sulfide concentrations $>20 \mathrm{mM}$ were reached below $10 \mathrm{~cm}$ and sulfate was depleted below. Layers of hydrate were found in several cores at depths of about $13-20 \mathrm{~cm}$. Strong degassing from decomposing hydrates was observed in several cores from Beggiatoa mats and in a few cores from Calyptogena fields. Sediments of the southern crest of Hydrate Ridge not covered by either community but sometimes containing bivalves of the species Acharax contained only traces of methane and sulfide in the upper $15 \mathrm{~cm}$ and are referred to as "reference" site. Upon 
TABLE 1 List of stations sampled during expedition SO143/2 (TECFLUX I) and SO148/1 (TECFLUX II)

\begin{tabular}{|c|c|c|c|c|c|}
\hline $\begin{array}{l}\text { Expedition/ } \\
\text { Station }\end{array}$ & $\begin{array}{c}\text { Date } \\
{[\mathrm{d} / \mathrm{m} / \mathrm{y}]}\end{array}$ & $\begin{array}{l}\text { Depth } \\
\text { [m] }\end{array}$ & Position & Site description & $\begin{array}{l}\text { Types of } \\
\text { analysis }\end{array}$ \\
\hline $143 / 91-1$ & 03.08 .99 & 850 & $\begin{array}{l}44^{\circ} 33.880^{\prime} \mathrm{N} \\
125^{\circ} 08.290^{\prime} \mathrm{W}\end{array}$ & $\begin{array}{c}\text { Reference (no } \\
\text { Acharax) }\end{array}$ & EEA \\
\hline $143 / 105-1$ & 05.08 .99 & 780 & $\begin{array}{l}44^{\circ} 34.140^{\prime} \mathrm{N} \\
125^{\circ} 08.810^{\prime} \mathrm{W}\end{array}$ & $\begin{array}{l}\text { Medium } \\
\quad \text { Beggiatoa mat }\end{array}$ & $\begin{array}{l}\text { TDR, EEA, } \\
\text { TCC, agg.no, } \\
\text { FISH }\end{array}$ \\
\hline $143 / 114-1$ & 07.08 .99 & 760 & $\begin{array}{l}44^{\circ} 34.210^{\prime} \mathrm{N} \\
125^{\circ} 09.850^{\prime} \mathrm{W}\end{array}$ & $\begin{array}{c}\text { Beggiatoa mat } \mathrm{w} \\
\text { Calyptogena }\end{array}$ & TDR, EEA \\
\hline $143 / 127-1$ & 09.08 .99 & 2321 & $\begin{array}{l}44^{\circ} 38.500^{\prime} \mathrm{N} \\
125^{\circ} 14.490^{\prime} \mathrm{W}\end{array}$ & $\begin{array}{l}\text { Reference (no } \\
\text { Acharax) }\end{array}$ & SRR \\
\hline $143 / 131-1$ & 10.08 .99 & 780 & $\begin{array}{l}44^{\circ} 34.180^{\prime} \mathrm{N} \\
125^{\circ} 08.800^{\prime} \mathrm{W}\end{array}$ & Calyptogena field & TDR, EEA \\
\hline $143 / 135-3$ & 11.08 .99 & 783 & $\begin{array}{l}44^{\circ} 34.196^{\prime} \mathrm{N} \\
125^{\circ} 08.825^{\prime} \mathrm{W}\end{array}$ & $\begin{array}{l}\text { Reference (few } \\
\text { Acharax) }\end{array}$ & EEA \\
\hline $143 / 139$ & 12.08 .99 & 830 & $\begin{array}{l}44^{\circ} 34.100^{\prime} \mathrm{N} \\
125^{\circ} 08.380^{\prime} \mathrm{W}\end{array}$ & $\begin{array}{l}\text { Reference (no } \\
\text { Acharax) }\end{array}$ & $\begin{array}{l}\text { EEA, SRR, } \\
\text { TCC, agg.no, } \\
\text { FISH }\end{array}$ \\
\hline $143 / 151-1$ & 13.08 .99 & 1284 & $\begin{array}{l}44^{\circ} 33.000^{\prime} \mathrm{N} \\
125^{\circ} 04.000^{\prime} \mathrm{W}\end{array}$ & $\begin{array}{l}\text { Reference (no } \\
\text { Acharax) }\end{array}$ & TDR \\
\hline $143 / 173-1$ & 16.08 .99 & 785 & $\begin{array}{l}44^{\circ} 34.160^{\prime} \mathrm{N} \\
125^{\circ} 08.850^{\prime} \mathrm{W}\end{array}$ & $\begin{array}{l}\text { Beggiatoa mat } \mathrm{w} \\
\text { Calyptogena }\end{array}$ & EEA, SRR \\
\hline $143 / 179-3$ & 17.08 .99 & 785 & $\begin{array}{l}44^{\circ} 34.210^{\prime} \mathrm{N} \\
125^{\circ} 08.740^{\prime} \mathrm{W}\end{array}$ & Calyptogena field & TDR, EEA, TCC \\
\hline $143 / 185-1$ & 18.08 .99 & 785 & $\begin{array}{l}44^{\circ} 34.190^{\prime} \mathrm{N} \\
125^{\circ} 08.830^{\prime} \mathrm{W}\end{array}$ & Calyptogena field & $\begin{array}{l}\text { TCC, agg.no, } \\
\text { FISH }\end{array}$ \\
\hline $143 / 187-1 / 4$ & 18.08 .99 & 785 & $\begin{array}{l}44^{\circ} 36.160^{\prime} \mathrm{N} \\
125^{\circ} 08.860^{\prime} \mathrm{W}\end{array}$ & $\begin{array}{l}\text { Medium } \\
\quad \text { Beggiatoa mat }\end{array}$ & TDR, EEA \\
\hline $143 / 190-1$ & 19.08 .99 & 825 & $\begin{array}{l}44^{\circ} 34.050^{\prime} \mathrm{N} \\
125^{\circ} 08.410^{\prime} \mathrm{W}\end{array}$ & $\begin{array}{l}\text { Reference (few } \\
\text { Acharax) }\end{array}$ & TDR \\
\hline $143 / 193-1$ & 20.08 .99 & 685 & $\begin{array}{l}44^{\circ} 37.509^{\prime} \mathrm{N} \\
124^{\circ} 55.970^{\prime} \mathrm{W}\end{array}$ & $\begin{array}{c}\text { Reference (no } \\
\text { Acharax) }\end{array}$ & EEA, TDR \\
\hline $148 / 19-2$ & 27.07 .00 & 777 & $\begin{array}{l}44^{\circ} 34.104^{\prime} \mathrm{N} \\
125^{\circ} 08.807^{\prime} \mathrm{W}\end{array}$ & $\begin{array}{l}\text { Medium } \\
\quad \text { Beggiatoa mat }\end{array}$ & $\begin{array}{r}\text { TCC, agg.no, } \\
\text { FISH, 16S }\end{array}$ \\
\hline $148 / 38-1$ & 30.07 .00 & 787 & $\begin{array}{l}44^{\circ} 34.186^{\prime} \mathrm{N} \\
125^{\circ} 08.847^{\prime} \mathrm{W}\end{array}$ & Calyptogena field & $\begin{array}{l}\text { TCC, agg.no, } \\
\text { FISH }\end{array}$ \\
\hline $148 / 51-1$ & 01.08 .00 & 775 & $\begin{array}{l}44^{\circ} 34.198^{\prime} \mathrm{N} \\
125^{\circ} 08.858^{\prime} \mathrm{W}\end{array}$ & $\begin{array}{l}\text { Reference (few } \\
\text { Acharax) }\end{array}$ & $\begin{array}{l}\text { TCC, agg.no, } \\
\text { FISH }\end{array}$ \\
\hline
\end{tabular}

Gas hydrates were recovered from cores with Beggiatoa at sediment depths $>13 \mathrm{~cm}$ and from $\mathrm{Ca}$ lyptogena fields ( $>16 \mathrm{~cm}$ ). Samples from Calyptogena fields contained 1-5 clams per core. "Beggiatoa mats" relate to cores covered by a carpet of Beggiatoa extending several $\mathrm{mm}$ into the overlying bottom water. Types of analysis: Bacterial secondary production measured as tymidine incorporation (TDR), total cell counts (TCC), aggregate numbers (agg.no), fluorescence in situ hybridization (FISH), 16S rDNA cloning (16S), sulfate reduction rates (SRR), extracellular enzyme activities (EEA). 
recovery sediment cores were immediately transferred to a cold room $\left(4^{\circ} \mathrm{C}\right)$. Samples were processed within $4 \mathrm{~h}$ after sampling according to the methods that follow.

\section{DNA Extraction}

Cores were sectioned into $1 \mathrm{~cm}$ layers and deep frozen $\left(-20^{\circ} \mathrm{C}\right)$ for DNA extraction at the home laboratory. Total community DNA was directly extracted from the sediment (Hydrate Ridge, station 19-2, Beggiatoa site) as described by Zhou et al. (1996). Aliquots (ca. $4 \mathrm{~g}$ ) of wet sediment of three different sections (depths, 0-1, 2-4, and 8-9 cm) were used for DNA extraction. Crude DNA was purified by dialysis as described previously (Ravenschlag et al. 2000).

\section{PCR Amplification and Clone Library Construction}

Two universal bacterial primers, GM3F (E. coli 16S rRNA position 0008; Muyzer et al. 1995) and EUB1492 (Kane et al. 1993), were used to amplify 16S rRNA genes from the extracted chromosomal DNAs. PCR was performed with a Mastercycler Gradient (Eppendorf, Hamburg, Germany) as described previously (Ravenschlag et al. 1999). Products of two parallel PCRs were combined and purified with the QiaQuick PCR Purification Kit using the protocol of the manufacturer (Qiagen, Hilden, Germany). DNA was ligated in the pGEM-T-Easy vector (Promega, Madison, WI, USA), and a clone library was constructed for each section $(0-1,2-4$, and $8-9 \mathrm{~cm})$ as described by Ravenschlag et al. (1999). The number of amplification cycles during PCR was reduced as much as possible to minimize PCR biases, chimera formations, and Taq polymerase error rates; however, 36 cycles were needed to yield sufficient product.

\section{ARDRA}

A total of 131 clones (01 cm: 34; $24 \mathrm{~cm}: 56 ; 89 \mathrm{~cm}$ : 41) known to contain the correctly sized insert of $1.5 \mathrm{~kb}$ were selected for further analysis. Amplified rDNA restriction analysis (ARDRA) was performed in order to identify clones with different inserts. Digestion with two restriction enzymes (HaeIII and RsaI) was used to screen the clones as described previously (Ravenschlag et al. 1999).

\section{Sequencing and Phylogenetic Analysis}

Representatives of all ARDRA pattern groups were used for sequencing. Taq Cycle Sequencing of plasmid DNAs from selected 16S rDNA clones with vector pimers and universal rRNA specific primers was performed by GATC Biotech (Konstanz, Germany) and GAG BioScience (Bremen, Germany). Sequence data were analyzed with the ARB software package (Strunk et al. 1998). Phylogenetic trees were calculated with sequences from Hydrate Ridge sediments together with sequences, which are available in the databases EMBL, GenBank, and DDJB, by performing parsimony, neighbor-joining, and maximumlikelihood analysis with different sets of filters. In all cases, general tree topology and clusters were stable. For tree calculation, nearly full length sequences ( $>1,340 \mathrm{bp})$ were considered. Partial sequences were inserted into the reconstructed tree by parsimony criteria with global/local optimization, without allowing changes in the overall tree topology. 


\section{Total Cell Counts, ANME-2/DSS Aggregate Numbers, and Size Measurements}

Samples for total cell counts were obtained from $1 \mathrm{~cm}$ core slices, fixed with $2 \%$ formaldehyde, and stored cold $\left(4^{\circ} \mathrm{C}\right)$ until analysis at the home laboratory. Total cell counts and the quantification of aggregates was done via epifluorescence microscopy after staining the sediments with Acridine Orange Direct Counts (AODC) according to the method of MeyerReil (1983). Total cell counts were defined as the sum of single cells plus the aggregated cells in the syntrophic consortia. In sediments from Hydrate Ridge, these ANME2/DSS aggregates can be easily recognized via AODC because of their conspicuous spherical shape and the surrounding organic matrix. However, the aggregated cells cannot be counted in these spheres. Hence, we used a semidirect method for the quantification of cells as described below. DAPI staining was used to measure ANME2/DSS aggregate sizes via epifluorescence microscopy of FISH-treated samples.

Five samples were selected for the measurement: Two horizons of the Beggiatoa mat (station 105-1: 1-2 cm, 9-10 cm) and the Calyptogena field (station 185-1: 1-2 cm, 9$10 \mathrm{~cm}$ ) and one sample of the reference (station 139: 0-1 cm), in which we detected the highest numbers of ANME2/DSS aggregates. For the upper layer of the Beggiatoa mat and Calyptogena field the diameter of 100 aggregates was measured, that of 50 aggregates for the other samples. Average diameters were between 3-4 $\mu \mathrm{m}$ in all cases (see Results), with a deviation of about $30 \%$ as standard deviation, and $10 \%$ as confidence level. We simply used $3 \mu \mathrm{m}$ as average aggregate diameter at all stations. Cell numbers in the aggregates were calculated based on the assumption that both the aggregates and the cells within the aggregates are spheres. The volume of the aggregate sphere (vol $\left.14 \mu \mathrm{m}^{3}\right)$ was divided by the volume of the cell (diameter ca. $0.4 \mu \mathrm{m}$ for SRB and $0.5 \mu \mathrm{m}$ for ANME2 cells, i.e., average $0.043 \mu \mathrm{m}^{3}$ ), resulting in an average cell number of ca. 300 cells (with ca. 200 SRB and 100 archaea (Boetius et al. 2000a).

Microbial biomass in gram carbon was calculated by multiplying cell numbers with a carbon content of $20 \mathrm{fg}$ per cell. This is a standard factor commonly used in aquatic microbial ecology and gives similar results to the other commonly used factor of $3 \times 10^{-13} \mathrm{gC} / \mu \mathrm{m}^{3}$ biovolume of cells (Børsheim et al. 1991).

\section{Fluorescence In Situ Hybridization (FISH)}

For FISH, subsamples of sediment cores were sliced into $1 \mathrm{~cm}$ intervals and fixed for $2-3 \mathrm{~h}$ with $3 \%$ formaldehyde (final concentration), washed twice with $1 \times$ PBS $(10 \mathrm{mM}$ sodium phosphate; $130 \mathrm{mM} \mathrm{NaCl}$ ), and finally stored in $1 \times \mathrm{PBS} / \mathrm{EtOH}(1: 1)$ at $-20^{\circ} \mathrm{C}$. Fixed samples were diluted and treated by mild sonication for $20 \mathrm{~s}$ with a MS73 probe (Sonopuls HD70, Bandelin, Germany) at an amplitude of $42 \mu \mathrm{m}<10 \mathrm{~W}$. An aliquot was filtered on $0.2 \mu \mathrm{m}$ GTTP polycarbonate filters (Millipore, Eschborn, Germany). Hybridization and microscopy counts of hybridized and 4',6'-diamidino-2-phenylindole (DAPI)-stained cells were performed as described previously (Snaidr et al. 1997). Means were calculated by using 10 to 40 randomly chosen fields for each filter section, which corresponded to 800 to 1000 DAPI-stained cells. Cy3-monolabeled oligonucleotides were purchased from ThermoHybaid (Ulm, Germany). Probes and formamide (FA) concentrations used in this study were as follows: EUB338 I-III targeting Bacteria (Daims et al. 1999; 35\% FA), ARCH915 targeting Archaea (Amann et al. 1990; 35\% FA), Non338 (negative control; Wallner et al. 1993; $10 \%$ FA), DSS658 targeting Desulfosarcina spp./Desulfococcus spp./Desulfofrigus spp. and Desulfofaba spp. (60\% FA), DSR651 targeting Desulfosarcina spp. (35\% FA), DSV698 targeting Desulfovibrio spp. (all in Manz et al. 1998; 35\% FA), 221 targeting Desulfobacterium spp. (35\% FA), 660 targeting Desulfobulbus spp. (Devereux et al. 1992; 60\% FA), Sva1428 targeting Desulfotalea spp./Desulfofustis spp./SEEP-SRB4/Desulfocapsa relatives (Sahm 
et al. 1999b; 35\% FA), and CF319a targeting the Cytophagal/Flavobacterium cluster (Manz et al. 1996; 35\% FA). Background signal of samples, observed with the nonsense probe NON338, was negligible $(<0.1 \%)$.

\section{Bacterial Secondary Production (Thymidine Incorporation)}

Thymidine incorporation was measured in slurries of $1 \mathrm{~cm}$ layers of sediment according to Boetius et al. (2000b). The procedure for the extraction of the DNA containing the ${ }^{3} \mathrm{H}-$ thymidine and the calculation of thymidine incorporation followed the method of Findlay (1993).

\section{Activity of Extracellular Hydrolytic Enzymes}

The extracellular enzymatic activities (EEA) of the hydrolases $\alpha$-, $\beta$-glucosidase, chitobiase, lipase, sulfatase, phosphatase, butyrase, and aminopeptidase were determined according to Boetius et al. (2000b) at in situ temperature $\left(2^{\circ} \mathrm{C}\right)$ in sediment slurries of $1 \mathrm{~cm}$ depth horizons.

\section{Sulfate Reduction Rates (SRR)}

Sediment cores collected from the multiple corer were subsampled with small PVC cores in the cold room $\left(4^{\circ} \mathrm{C}\right)$, and ${ }^{35} \mathrm{SO}_{4}^{2-}$ was injected horizontally into the intact sediment cores at $1-\mathrm{cm}$ depth intervals. The cores were incubated for $24 \mathrm{~h}$ at in situ temperature before the reaction was stopped by sectioning the sediments at $1 \mathrm{~cm}$ intervals and mixing with $20 \%$ zinc acetate. The samples were stored frozen until the single-step acidic distillation of the Cr-II-reduced sulfur compounds was carried out as described by Fossing and Jørgensen (1989). SRR was calculated from the ratio of radioactive sulfide to the total radioactive sulfate added, multiplied by the porewater sulfate concentration. Sulfate concentrations and porosity data for calculating the rates were kindly provided by D. Rickert (GEOMAR).

\section{Nucleotide Sequence Accession Numbers}

The nucleotide sequence data reported in this paper will appear in the EMBL, GenBank, and DDBJ nucleotide sequence database under the accession no. AF535216 to AF535259.

\section{Results}

\section{Bacterial Abundance and Secondary Production}

The abundance of single cells was compared among the sulfidic, hydrate-bearing sediments recovered from Beggiatoa mats and Calyptogena fields and the sediments of a reference station, which was not substantially enriched in methane in the upper $10 \mathrm{~cm}$ (Figure 1, Table 2). In the top centimeter layer of methane-rich sediments, numbers of single cells were $4.5 \times 10^{9}$ cells $\mathrm{cm}^{-3}$ and significantly higher than at the reference site $\left(1 \times 10^{9}\right.$ cells $\mathrm{cm}^{-3}$ ). Counts of single cells in the strongly sulfidic Beggiatoa mat dropped quickly to around $1 \times 10^{9}$ cells $\mathrm{cm}^{-3}$ below sediment surface, and were only slightly higher than at the reference site. However, cell counts in sediments of the Calyptogena field remained high down to $25 \mathrm{~cm}$. A high number of aggregated cells $\left(>10^{8}\right.$ aggregates $\left.\mathrm{cm}^{-3}\right)$ was detected in the sediments above hydrate by the characteristic fluorescent green of nucleic acid staining with Acridine Orange (AO). The aggregates were enclosed in an organic matrix, which was 

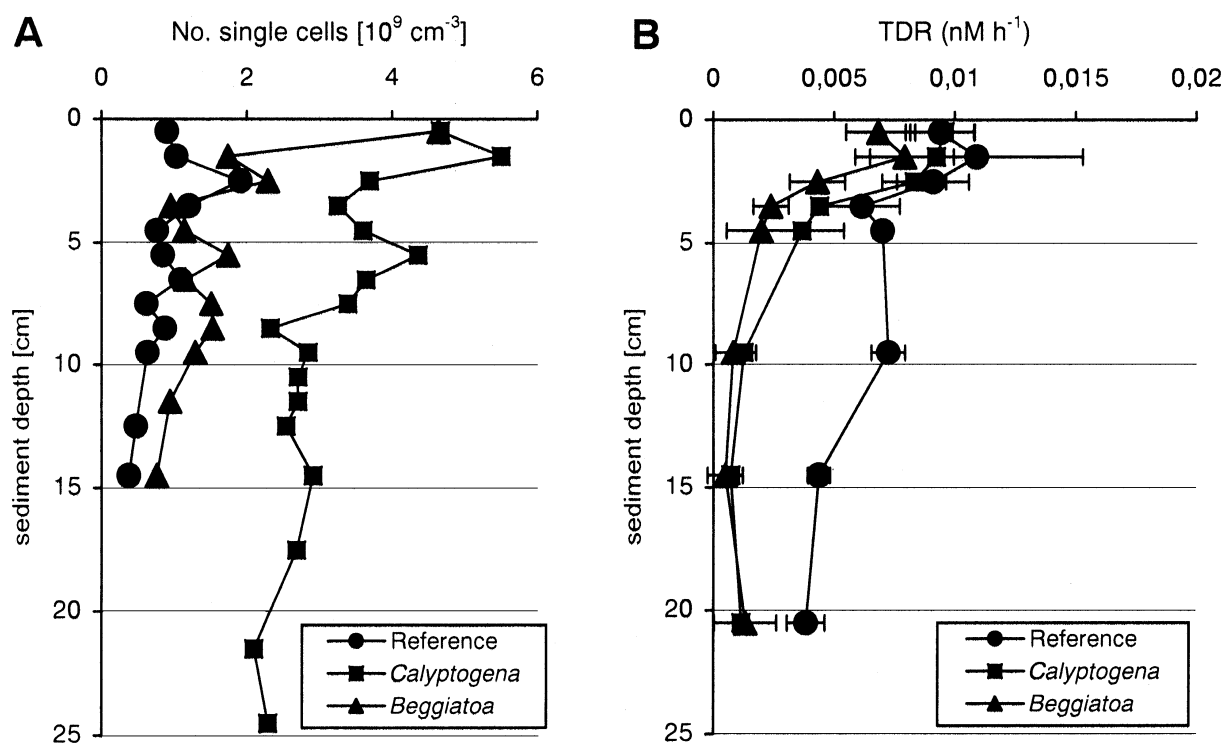

FIGURE 1 (A) Depth profile of total single cells as detected by AODC at the Beggiatoa site (station 105), Calyptogena field (station 179), and reference site (station 139). (B) Depth profile of bacterial production measured as thymidine incorporation into DNA in samples of Beggiatoa mats (mean of stations 105, 114, 187), Calyptogena fields (mean of stations 131, 179), and reference stations (mean of stations 151, 190, 193).

stained orange by AO. These cell aggregates could not be separated by sonification and were counted separately (see below). Using specific probes targeting the ANME2 archaea and DSS bacteria, these aggregates were identified as the syntrophic consortia responsible for anaerobic oxidation of methane.

Thymidine incorporation into DNA (TDR) was measured as an indicator of bacterial secondary production. In contrast to bacterial abundance, highest TDR were measured at the reference site. In the top surface layer, TDR was around $0.007 \mathrm{nM} \mathrm{h}^{-1}$ at the Beggiatoa mat and $0.01 \mathrm{nM} \mathrm{h}^{-1} \mathrm{TDR}$ at the Calyptogena field and the reference site. TDR dropped to lowest values in the strongly sulfidic sediments of the Beggiatoa mat. No relation between bacterial abundance and growth rate was detected with this method.

\section{Activity of Extracellular Hydrolytic Enzymes}

Activities of the hydrolytic enzymes $\alpha$-glucosidase, $\beta$-glucosidase, chitobiase, lipase, phosphatase, sulfatase, butyrase, and peptidase were measured in the sediments above hydrate and at a reference station. Generally, extracellular enzyme activities (EEA) were highest in the top cm layer of sediment and decreased quickly with depth (Figure 2). No substantial differences between sites were found comparing esterases and peptidases. In hydrate-bearing sediments, enzyme activities of the glucosidases ( $\alpha$-, $\beta$-glucosidase, chitobiase) declined to low or nondetectable EEA with increasing sediment depth, i.e., sulfide concentration. In subsurface sediments of Calyptogena fields EEA were generally higher than in Beggiatoa mats. Highest EEA were measured in the subsurface sediments of the reference site. Only the enzyme sulfatase showed highest activities in the hydrate-bearing sediments. A maximum was found in the top cm of the Beggiatoa mats, medium values in the Calyptogena fields, and lowest sulfatase EEA at the reference site. 

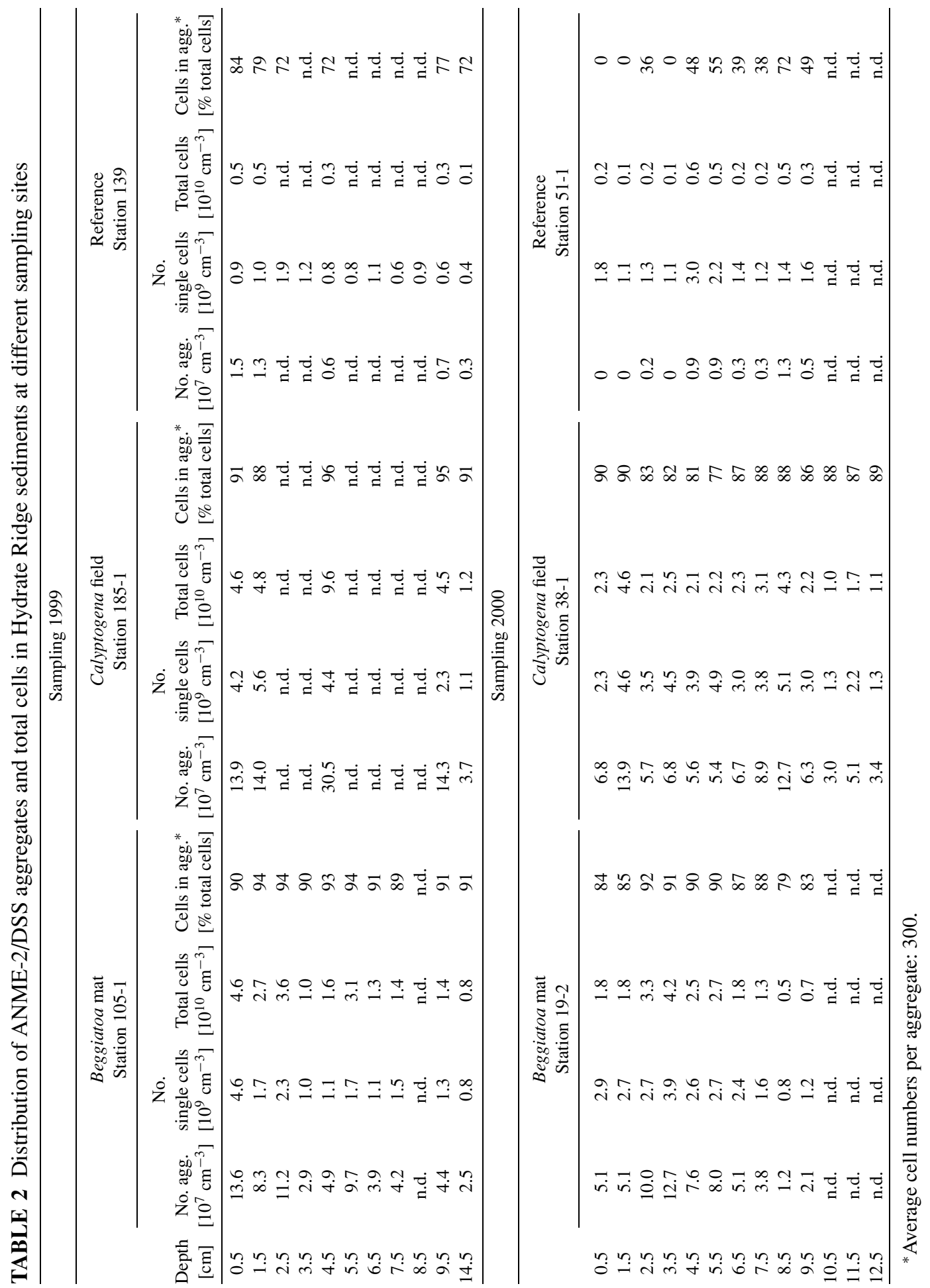


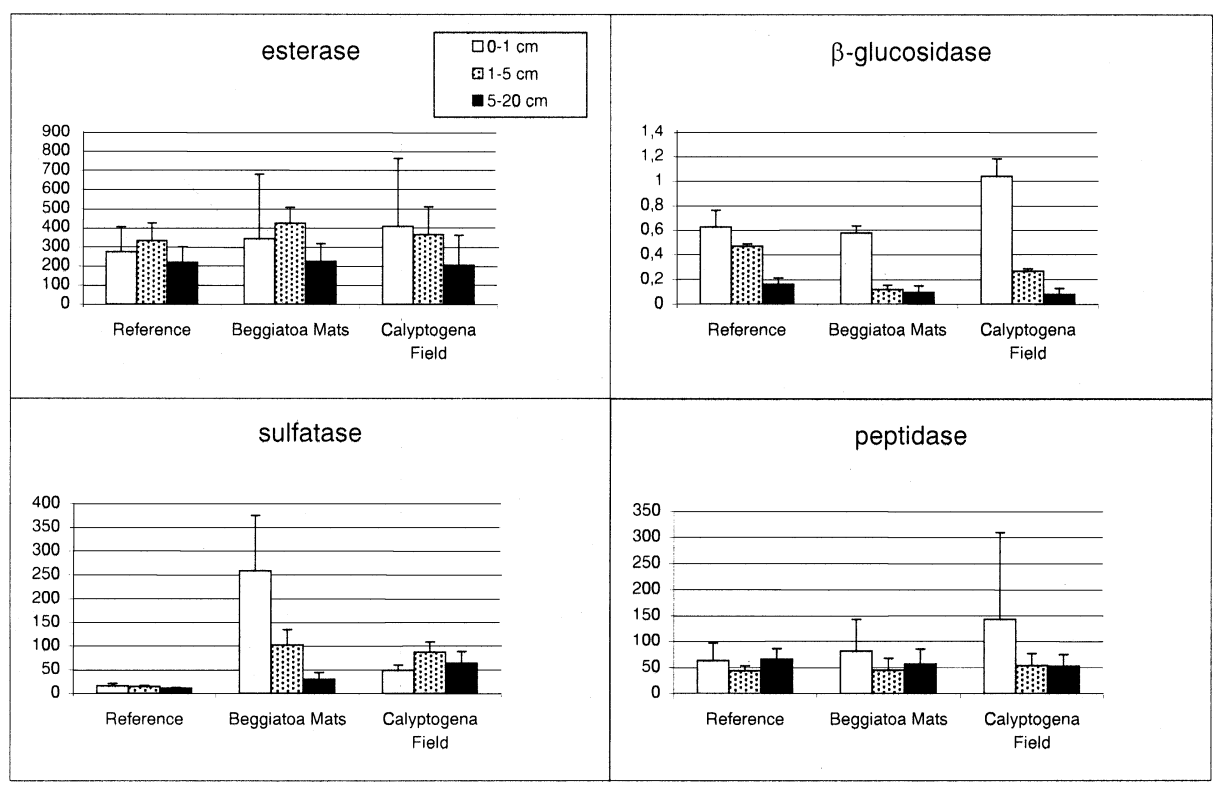

FIGURE 2 Comparison of extracellular hydrolytic activities of different enzymes at different study sites (sampling 1999) and sediment depth horizons at Hydrate Ridge. Activities are given in $\mathrm{nmol} \mathrm{cm} \mathrm{cm}^{-3} \mathrm{~h}^{-1}$, Beggiatoa mat: mean of stations 105, 114, 173, 187; Calyptogena field: mean of stations 114, 131, 135, 173, 179; reference stations: mean of stations 91, 139, 193.

\section{Sulfate Reduction Rates}

Differences between hydrate-bearing and reference sites were most obvious when comparing sulfate reduction rates (SRR, Figure 3). SRR was two orders of magnitude higher above hydrate than at the reference site (Figure 3C). Also, a difference was noted between SRR in cores from Beggiatoa mats (Figure 3A) and Calyptogena fields (Figure 3B). Generally, samples from Calyptogena fields had a subsurface maximum in SRR whereas Beggiatoa mats often showed highest SRR in the top $2 \mathrm{~cm}$ of sediments. A considerable variation
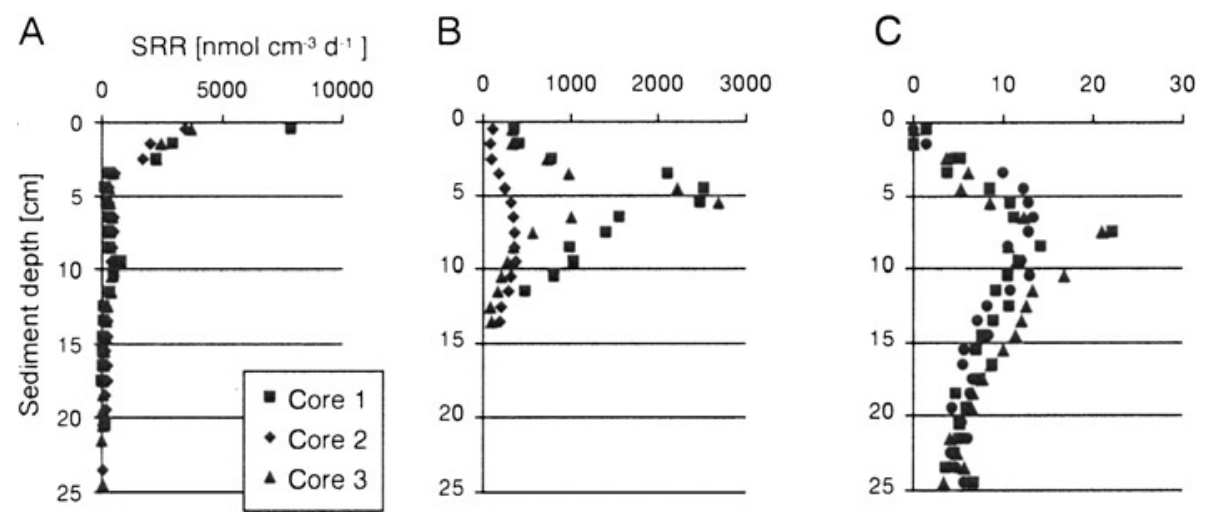

FIGURE 3 Depth profiles of sulfate reduction rates (SRR) in three parallel sediment cores of different sampling sites of Hydrate Ridge (sampling 1999). (A) Beggiatoa mat (station 173); (B) Calyptogena field (station 173); (C) reference station (station 127). 
A ANME-2/DSS aggregate numbers $\left[10^{7} \mathrm{~cm}^{-3}\right]$

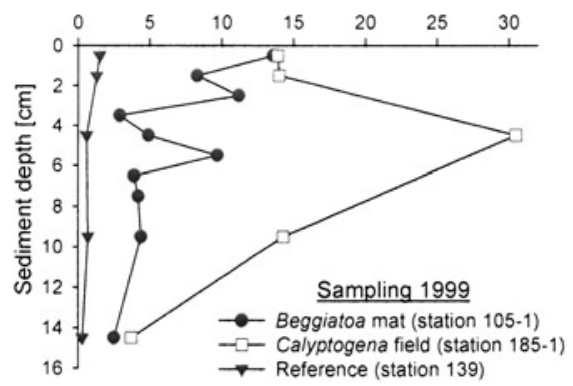

B ANME-2/DSS aggregate numbers $\left[10^{7} \mathrm{~cm}^{-3}\right]$

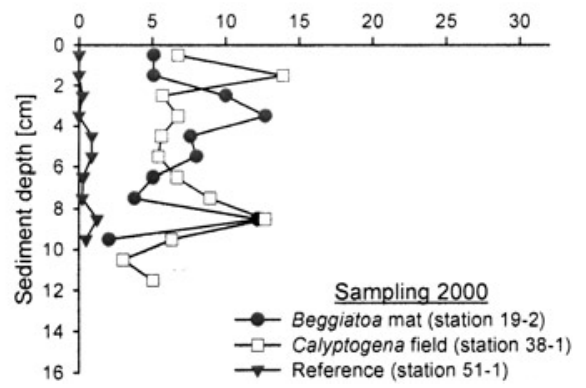

FIGURE 4 Depth profile of ANME-2/DSS aggregate numbers at different sampling sites.

between cores within one bacterial mat or clam field was observed in 1999 (Figure 3) and also in 2000 (data not shown). Integrated sulfate reduction rates in the upper $10 \mathrm{~cm}$ were 8,4 , and $0.05 \mu \mathrm{mol} \mathrm{cm}^{-2} \mathrm{~d}^{-1}$ in 1999 and 3, 6.5, and $0.03 \mu \mathrm{mol} \mathrm{cm}^{-2} \mathrm{~d}^{-1}$ in 2000 in Beggiatoa mats, Calyptogena fields, and the reference sites, respectively.

\section{ANME-2/DSS Aggregate Sizes, Numbers, and Total Cell Counts}

Numbers of ANME-2/DSS aggregates and total cells (single cells plus cells in aggregates) were determined in Hydrate Ridge sediments at six different sampling sites (Beggiatoa mats, Calyptogena mats, and reference stations). ANME-2/DSS aggregates were present in all sediments investigated (Figure 4, Table 2). At the reference station aggregate numbers were one to two orders of magnitude lower or aggregates were absent. All aggregates were similarly structured and consisted of an inner core containing archaeal cells partially or fully surrounded by SRB which form an outer shell of 1-2 layers as described previously (Boetius et al. 2000a). We did not find evidence for other bacterial associations with the methane-oxidizing archaeal ANME-2 group. Aggregations of ANME-2 without bacterial partners were also not detected. The size spectrum of ANME-2/DSS aggregates ranged from 1 to $12 \mu \mathrm{m}$ in diameter (Figure 5). The size of aggregates did not change significatly with depth and between study sites (Beggiatoa mat: 1-2 cm: $3.2 \pm 1.5 \mu \mathrm{m}$, range 1-12 $\mu \mathrm{m}$ and 9-10 cm: $4.1 \pm 1.4 \mu \mathrm{m}$, range $2-10 \mu \mathrm{m}$; Calyptogena field: $1-2 \mathrm{~cm}: 3.9 \pm 1.4 \mu \mathrm{m}$, range $2-8 \mu \mathrm{m}$ and $9-10 \mathrm{~cm}: 4.0 \pm 1.4 \mu \mathrm{m}$, range $2-6 \mu \mathrm{m}$; reference: $0-1 \mathrm{~cm}: 3.7 \pm 1.6 \mu \mathrm{m}$, range $2-10 \mu \mathrm{m})$.

Aggregate numbers were highest in sediments from Calyptogena fields with $31 \times$ $10^{7} \mathrm{~cm}^{-3}$ at $4.5 \mathrm{~cm}$ depth (station 185-1, 1999). At station 38-1 (2000) the average aggregate numbers were slightly lower with two maxima at $1.5 \mathrm{~cm}$ and $8.5 \mathrm{~cm}$ depth and 14 and $13 \times 10^{7}$ aggregates per $\mathrm{ml}$ sediment, respectively. In sediments covered by Beggiatoa mats aggregate numbers ranged from $2.5 \times 10^{7} \mathrm{~cm}^{-3}$ up to $14 \times 10^{7} \mathrm{~cm}^{-3}$ (station 105-1, 1999) and 1.2 to $12.7 \times 10^{7} \mathrm{~cm}^{-3}$ sediment (station 19-2,2000). At the reference station aggregate numbers ranged from 0 to a $1.5 \times 10^{7} \mathrm{~cm}^{-3}$.

Due to the high aggregate numbers in the hydrate-bearing sediments total cell numbers were very high at the Beggiatoa mats and Calyptogena fields. Total cell numbers ranged from 1.2 to $9.6 \times 10^{10}$ (station 185-1) and 1.0 to $4.6 \times 10^{10}$ cells cm${ }^{-3}$ (station 38-1) in sediments covered by Calyptogena. Below the Beggiatoa mat numbers ranged from 4.6 to $0.8 \times 10^{10} \mathrm{~cm}^{-3}$ (station 105-1) and 0.5 to $4.2 \times 10^{10} \mathrm{~cm}^{-3}$ sediment (station 19-2). As a percentage, ANME-2/DSS aggregates accounted for more than three-quarters of total cells $(77$ to $95 \%)$ in hydrate-bearing sediments. At the reference station these values were generally significantly lower and ranged from 1 to $5 \times 10^{9} \mathrm{~cm}^{3}$ (Table 2). These high cell 

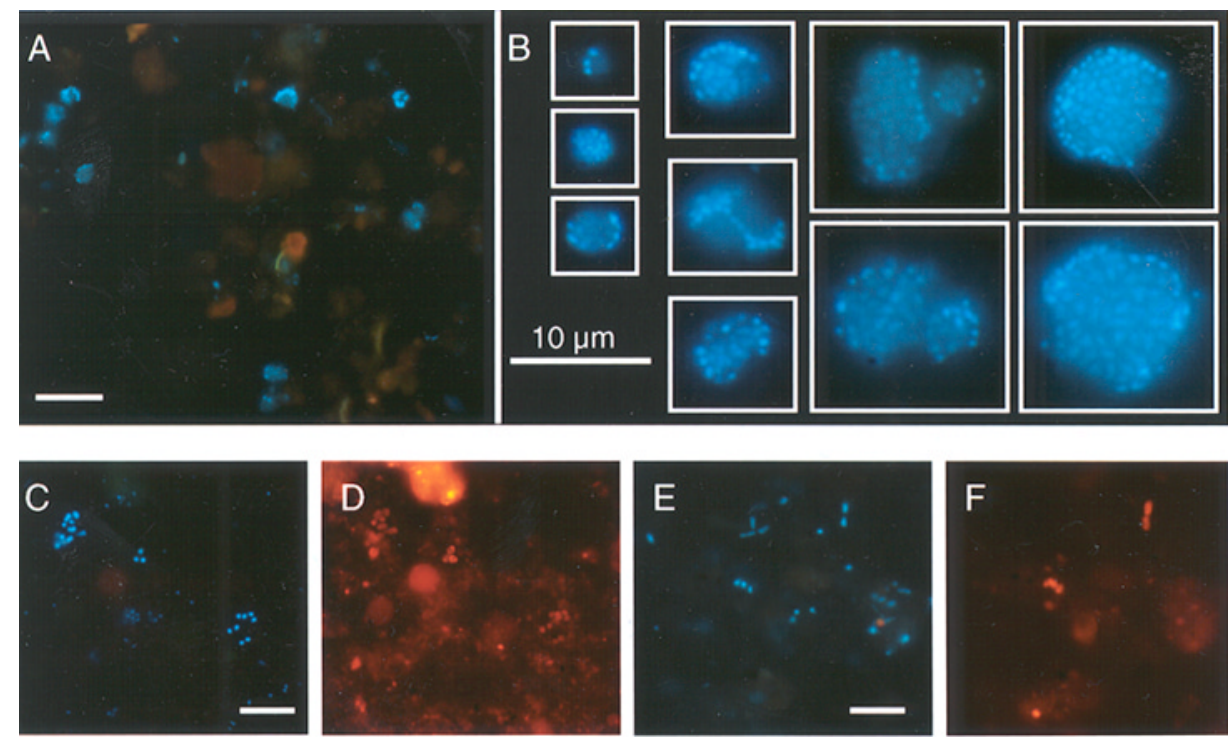

FIGURE 5 Epifluorescence micrographs of structured ANME-2/DSS aggregates and other bacteria in sediment samples from Hydrate Ridge. (A, B) Size spectrum of DAPI stained ANME-2/DSS aggregates. (C, D) DAPI staining and FISH with probe DSS658 specific for the Desulfosarcina/Desulfococcus branch (same microscopic field). (E, F) DAPI staining and FISH with probe DSR651 specific for the Desulforhopalus spp. (same microscopic field). The scale bar is equivalent to $10 \mu \mathrm{m}$.

numbers correspond to extremely high microbial biomass of 5,13 , and $0.8 \mathrm{mg} \mathrm{C} \mathrm{cm}^{-2}$ in 1999 and 4.5, 6, and $0.6 \mathrm{mg} \mathrm{C} \mathrm{cm}^{-2}$ in 2000 integrated over the upper $10 \mathrm{~cm}$ of sediment from Beggiatoa mats, Calyptogena fields, and the reference sites, respectively.

\section{FISH Detection Rates}

A high quantity of DAPI-stained single cells was detected by domain specific probes EUB338 I-III (Bacteria) and ARCH915 (Archaea) in sediments above hydrate (Table 3). At the Beggiatoa and Calyptogena sites detection of Bacteria ranged between 40 and 52\% at the sediment surface and was highest with $62 \%$ in $1.5 \mathrm{~cm}$ depth (Calyptogena field, station 38-1). Below this depth the detection rate strongly decreased to less than $10 \%$ of total DAPI cell counts. In contrast, detection rates for single cell Archaea increased with increasing depth. At the sediment surface detection of such Archaea was relatively low with $1-2 \%$ in sediments from the Calyptogena field and Beggiatoa mat and increased strongly to $18-31 \%$ in 9.5 to $14.5 \mathrm{~cm}$ depth. Significant differences in presence and abundance of specific phylogenetic groups were not observed between Beggiatoa and Calyptogena covered sediments. At the reference stations detection rates of Bacteria were low with only $<19 \%$ of total single cells. Archaea detection was highest in $8.5 \mathrm{~cm}$ depth with $4 \%$ of total DAPI single cell counts, i.e., up to one order of magnitude lower than in hydrate-bearing sediments.

\section{SRB Community Structure}

The SRB communities in sediments covered by Beggiatoa or Calyptogena were dominated by complete oxidizers of the Desulfosarcina/Desulfococcus branch (probe DSS658). Up to 
TABLE 3 Quantification of single Bacteria, Archaea, SRB, and members of the Cytophaga/Flavobacterium cluster by FISH

\begin{tabular}{|c|c|c|c|c|c|c|c|c|c|}
\hline \multicolumn{10}{|c|}{ Sampling 1999} \\
\hline \multirow[t]{2}{*}{$\begin{array}{l}\text { Depth } \\
{[\mathrm{cm}]}\end{array}$} & $\begin{array}{c}\text { Bacteria } \\
\text { (EUB338 I-III) }\end{array}$ & $\begin{array}{c}\text { Archaea } \\
\text { (ARCH915) }\end{array}$ & $\begin{array}{c}D^{\prime} \text { sarcina } \\
D^{\prime} \text { coccus } \\
\text { spp. } \\
\text { (DSS658) }\end{array}$ & $\begin{array}{c}\text { Desulfo- } \\
\text { rhopalus } \\
\text { spp. } \\
\text { (DSR651) }\end{array}$ & $\begin{array}{l}\text { Desulfo- } \\
\text { vibrio } \\
\text { spp. } \\
\text { (DSV698) }\end{array}$ & $\begin{array}{c}\text { Desulfo- } \\
\text { bacterium } \\
\text { spp. } \\
(221)\end{array}$ & $\begin{array}{c}\text { Desulfo- } \\
\text { talea } \\
\text { spp. } \\
\text { (Sval428) }\end{array}$ & $\begin{array}{c}\text { Desulto- } \\
\text { bulbus } \\
\text { spp. } \\
\text { (660) }\end{array}$ & $\begin{array}{c}\text { Cytophag } \\
\text { Flavobac } \\
\text { spp. } \\
\text { (CF319a }\end{array}$ \\
\hline & \multicolumn{9}{|c|}{$\begin{array}{c}\text { Beggiatoa mat } \\
\text { Station 105-1 }\end{array}$} \\
\hline 0.5 & 52 & 1 & 1 & 4 & $<1$ & 0 & 2 & $<0.5$ & 5 \\
\hline 1.5 & 22 & 4 & 4 & 2 & $<1$ & 0 & 0 & $<1$ & 4 \\
\hline 2.5 & 24 & 2 & 2 & 1 & $<0.5$ & 0 & 0 & $<0.5$ & 1 \\
\hline 3.5 & 20 & 1 & 3 & $<1$ & 0 & 0 & 1 & 0 & $<0.5$ \\
\hline 4.5 & 21 & 7 & 2 & $<0.5$ & 0 & n.d. & $<1$ & 0 & $<1$ \\
\hline 5.5 & 20 & 3 & 1 & $<0.5$ & n.d. & $<1$ & 2 & 0 & 1 \\
\hline 6.5 & 18 & 1 & 2 & $<0.5$ & 0 & 0 & 0 & $<0.5$ & 1 \\
\hline 7.5 & 17 & 5 & 2 & $<0.5$ & 0 & 0 & 0 & 0 & 0 \\
\hline 9.5 & 12 & 23 & 4 & 0 & 0 & 0 & 0 & 0 & 0 \\
\hline \multirow[t]{2}{*}{14.5} & 15 & 14 & 1 & $<0.5$ & 0 & 0 & $<1$ & 0 & 0 \\
\hline & \multicolumn{9}{|c|}{$\begin{array}{l}\text { Calyptogena field } \\
\text { Station } 185-1\end{array}$} \\
\hline 0.5 & 48 & 3 & 3 & $<1$ & $<0.5$ & 0 & $<0.5$ & 0 & 0 \\
\hline 1.5 & 25 & 2 & 2 & $<1$ & $<0.5$ & 0 & $<0.5$ & 0 & 3 \\
\hline 2.5 & n.d. & n.d. & n.d. & n.d. & n.d. & n.d. & n.d. & n.d. & n.d. \\
\hline 3.5 & n.d. & n.d. & n.d. & n.d. & n.d. & n.d. & n.d. & n.d. & n.d. \\
\hline 4.5 & 18 & 23 & 1 & $<1$ & 0 & 0 & 0 & 0 & $<1$ \\
\hline 5.5 & n.d. & n.d. & n.d. & n.d. & n.d. & n.d. & n.d. & n.d. & n.d. \\
\hline 6.5 & n.d. & n.d. & n.d. & n.d. & n.d. & n.d. & n.d. & n.d. & n.d. \\
\hline 7.5 & n.d. & n.d. & n.d. & n.d. & n.d. & n.d. & n.d. & n.d. & n.d. \\
\hline 9.5 & 15 & 30 & 5 & 0 & 0 & 0 & 0 & $<0.5$ & $<0.5$ \\
\hline \multirow[t]{2}{*}{14.5} & 9 & 28 & 0 & 0 & 0 & 0 & $<0.5$ & $<0.5$ & 0 \\
\hline & \multicolumn{9}{|c|}{$\begin{array}{c}\text { Reference } \\
\text { Station } 139\end{array}$} \\
\hline 0.5 & 17 & $<1$ & $<1$ & $<1$ & $<1$ & 0 & $<1$ & 0 & $<1$ \\
\hline 1.5 & 19 & $<1$ & 1 & $<0.5$ & $<1$ & 0 & 0 & 0 & $<1$ \\
\hline 2.5 & n.d. & n.d. & n.d. & n.d. & n.d. & n.d. & n.d. & n.d. & n.d. \\
\hline 3.5 & n.d. & n.d. & n.d. & n.d. & n.d. & n.d. & n.d. & n.d. & n.d. \\
\hline 4.5 & 11 & $<0.5$ & $<1$ & 0 & 0 & 0 & 0 & 0 & 2 \\
\hline 5.5 & n.d. & n.d. & n.d. & n.d. & n.d. & n.d. & n.d. & n.d. & n.d. \\
\hline 6.5 & n.d. & n.d. & n.d. & n.d. & n.d. & n.d. & n.d. & n.d. & n.d. \\
\hline 7.5 & n.d. & n.d. & n.d. & n.d. & n.d. & n.d. & n.d. & n.d. & n.d. \\
\hline 9.5 & n.d. & n.d. & $<0.5$ & 0 & n.d. & 0 & 0 & 0 & 2 \\
\hline 14.5 & n.d. & n.d. & $<0.5$ & 0 & 0 & 0 & 0 & 0 & 0 \\
\hline
\end{tabular}

Sampling 2000

Beggiatoa mat

Station $19-2$

$\begin{array}{rrrrcccccc}0.5 & 40 & 1 & <1 & 2 & <1 & 0 & 0 & 0 & 1 \\ 1.5 & 17 & 1 & 2 & <0.5 & \text { n.d. } & \text { n.d. } & \text { n.d. } & \text { n.d. } & <1 \\ 2.5 & 24 & 3 & 2 & <0.5 & 0 & 0 & 0 & 0 & <0.5 \\ 3.5 & 15 & 1 & 2 & <0.5 & \text { n.d. } & \text { n.d. } & \text { n.d. } & \text { n.d. } & <0.5 \\ 4.5 & 9 & 3 & <1 & <0.5 & 0 & 0 & 0 & 0 & <0.5 \\ 5.5 & 14 & 4 & <1 & <0.5 & \text { n.d. } & \text { n.d. } & \text { n.d. } & \text { n.d. } & <0.5 \\ 6.5 & 7 & 9 & 1 & 0 & 0 & 0 & 0 & 0 & 0 \\ 7.5 & 8 & 25 & 1 & 0 & \text { n.d. } & \text { n.d. } & \text { n.d. } & \text { n.d. } & 0 \\ 8.5 & 7 & 22 & <1 & 0 & 0 & 0 & 0 & 0 & 0 \\ 9.5 & 9 & 18 & 5 & 0 & \text { n.d. } & \text { n.d. } & \text { n.d. } & \text { n.d. } & 0 \\ 10.5 & \text { n.d. } & \text { n.d. } & \text { n.d. } & \text { n.d. } & \text { n.d. } & \text { n.d. } & \text { n.d. } & \text { n.d. } & \text { n.d. } \\ 11.5 & \text { n.d. } & \text { n.d. } & \text { n.d. } & \text { n.d. } & \text { n.d. } & \text { n.d. } & \text { n.d. } & \text { n.d. } & \text { n.d. }\end{array}$


TABLE 3 Quantification of single Bacteria, Archaea, SRB, and members of the Cytophaga/Flavobacterium cluster by FISH (Continued)

\begin{tabular}{|c|c|c|c|c|c|c|c|c|c|}
\hline \multicolumn{10}{|c|}{ Sampling 2000} \\
\hline $\begin{array}{l}\text { Depth } \\
{[\mathrm{cm}]}\end{array}$ & $\begin{array}{c}\text { Bacteria } \\
\text { (EUB338 I-III) }\end{array}$ & $\begin{array}{c}\text { Archaea } \\
\text { (ARCH915) }\end{array}$ & $\begin{array}{c}D^{\prime} \text { sarcina } \\
D^{\prime} \text { coccus } \\
\text { spp. } \\
\text { (DSS658) }\end{array}$ & $\begin{array}{l}\text { Desulfo- } \\
\text { rhopalus } \\
\text { spp. } \\
\text { (DSR651) }\end{array}$ & $\begin{array}{c}\text { Desulfo- } \\
\text { vibrio } \\
\text { spp. } \\
\text { (DSV698) }\end{array}$ & $\begin{array}{c}\text { Desulfo- } \\
\text { bacterium } \\
\text { spp. } \\
(221)\end{array}$ & $\begin{array}{c}\text { Desulfo- } \\
\text { talea } \\
\text { spp. } \\
\text { (Sval428) }\end{array}$ & $\begin{array}{c}\text { Desulto- } \\
\text { bulbus } \\
\text { spp. } \\
(660)\end{array}$ & $\begin{array}{c}\text { Cytophaga } \\
\text { Flavobact. } \\
\text { spp. } \\
\text { (CF319a) }\end{array}$ \\
\hline \multicolumn{10}{|c|}{ Calyptogena field } \\
\hline 0.5 & 47 & 2 & 1 & $<1$ & 0 & $<0.5$ & 0 & 0 & 3 \\
\hline 1.5 & 62 & $<1$ & $<1$ & $<1$ & n.d. & n.d. & n.d. & n.d. & 1 \\
\hline 2.5 & 39 & 1 & 2 & $<0.5$ & 0 & $<1$ & 0 & 0 & $<1$ \\
\hline 3.5 & 31 & 4 & 1 & $<0.5$ & n.d. & n.d. & n.d. & n.d. & $<1$ \\
\hline 4.5 & 30 & 4 & 2 & $<0.5$ & 0 & $<0.5$ & 0 & 0 & $<1$ \\
\hline 5.5 & 12 & 16 & $<1$ & 0 & n.d. & n.d. & n.d. & n.d. & $<0.5$ \\
\hline 6.5 & 6 & 13 & 2 & 0 & 0 & 0 & 0 & 0 & 0 \\
\hline 7.5 & 5 & 15 & 2 & 0 & n.d. & n.d. & n.d. & n.d. & 0 \\
\hline 8.5 & 3 & 12 & 4 & 0 & 0 & 0 & 0 & 0 & $<0.5$ \\
\hline 9.5 & 2 & 19 & $<0.5$ & $<0.5$ & n.d. & n.d. & n.d. & n.d. & $<0.5$ \\
\hline 10.5 & 1 & 22 & 1 & 0 & 0 & 0 & 0 & 0 & $<0.5$ \\
\hline 11.5 & n.d. & 26 & 5 & $<0.5$ & n.d. & n.d. & n.d. & n.d. & 0 \\
\hline \multicolumn{10}{|c|}{$\begin{array}{c}\text { Reference } \\
\text { Station 51-1 }\end{array}$} \\
\hline 0.5 & 16 & 0 & 1 & 0 & $<0.5$ & 0 & 0 & 0 & 1 \\
\hline 1.5 & 13 & 0 & 2 & 0 & n.d. & n.d. & n.d. & n.d. & 1 \\
\hline 2.5 & 12 & $<0.5$ & 1 & 0 & 0 & $<0.5$ & 0 & 0 & $<1$ \\
\hline 3.5 & 15 & 0 & $<1$ & 0 & n.d. & n.d. & n.d. & n.d. & $<1$ \\
\hline 4.5 & 13 & 2 & $<1$ & 0 & 0 & 0 & 0 & 0 & $<1$ \\
\hline 5.5 & 10 & 2 & $<0.5$ & $<0.5$ & n.d. & n.d. & n.d. & n.d. & 0 \\
\hline 6.5 & 12 & 2 & 3 & $<1$ & 0 & 0 & 0 & 0 & $<0.5$ \\
\hline 7.5 & 6 & 2 & 4 & 0 & n.d. & n.d. & n.d. & n.d. & 0 \\
\hline 8.5 & 12 & 4 & 3 & 0 & 0 & 0 & 0 & 0 & 0 \\
\hline 9.5 & 12 & 3 & 2 & 1.0 & n.d. & n.d. & n.d. & n.d. & 0 \\
\hline 10.5 & n.d. & n.d. & n.d. & n.d. & n.d. & n.d. & n.d. & n.d. & n.d. \\
\hline 11.5 & n.d. & n.d. & n.d. & n.d. & n.d. & n.d. & n.d. & n.d. & n.d. \\
\hline
\end{tabular}

n.d.: not determined.

Numbers given in percent of DAPI detected single cells, probe names are in parenthesis.

$5 \%$ of total single cells (up to $0.7 \times 10^{8}$ cells cm $\mathrm{cm}^{-3}$ Beggiatoa mat and $2.2 \times 10^{8}$ cells cm $^{-3}$ Calyptogena field) were detected with this probe by FISH. These unassociated members of the Desulfosarcina/Desulfococcus branch made up 18-100\% of total detected single SRB. Detection of this group along the vertical profile showed several maxima and was highest at $1.5 \mathrm{~cm} \mathrm{(4 \% )} \mathrm{and} 9.5 \mathrm{~cm}(5 \%)$ depth in the Beggiatoa mat and at $9.5 \mathrm{~cm}(5 \%)$ and $11.5 \mathrm{~cm}$ $(5 \%)$ in the Calyptogena filed. Typically, the DSS658-positive cells showed a sarcina-like cell morphology (Figure 5). The cells were irregularly shaped cocci of about $0.5-1 \mu \mathrm{m}$ in diameter and occurred in sarcina-like tetrades, in large clusters of 5-15 or even more cells or very often as diplococci.

The second dominant population, but with much lower abundance, were members of the Desulforhopalus (cluster). Probe DSR651 detected a maximum of $4 \%$ of all single cells $\left(1.7 \times 10^{8}\right.$ cells $\left.\mathrm{cm}^{-3}\right)$ by FISH. Detection was highest at the surface layer in all sediments and decreased strongly with depth. In deeper layers detection rate were close to detection limit. Detection with probe Sva1428 that is specific for Desulfotalea/Desulfofustis/SEEPSRB4/Desulfocapsa relatives was lower than for DSR651 although DSR651 is a nested 
probe for Sva1428. We only found relevant detection rates at one Beggiatoa site (station 105-1) with maximum $2 \%$ of total single cells at the sediment surface and $2 \%$ in $5.5 \mathrm{~cm}$ depth. In sediments covered by Calyptogena fields Sva1428-targeted SRB were detected, but at numbers very close to the detection limit. Probe Sva1428 was originally designed to target Desulfotalea species (Sahm et al. 1999b). However, while databases increases, unspecificity of this probe turned out. The underestimation of the Sva1428-target groups could be explained by a lack of detectability due to the frequently observed weak probe signals in sediment samples. Cells with a low rRNA content will probably not be detected by this probe. Desulfovibrio species frequently cultivated in coastal marine sediments could only be detected in the upper layers (surface layer to $2.5 \mathrm{~cm}$ depth) with low numbers of $1 \%$ of DAPI cell counts at maximum $\left(0.14 \times 10^{8}\right.$ cells $\left.\mathrm{cm}^{-3}\right)$. The cell morphology was not vibrio-like as typical for Desulfovibrio species, but short or long thin rods and few coccoidal cells. This can be due to probe unspecificity but there are also rod-shaped Desulfovibrio species, e.g., Desulfovibrio piger or Desulfovibrio carbinolicus (Widdel and Bak 1992a). Members of the genus Desulfobacterium (probe 221), completely oxidizing bacteria, and Desulfobulbus (probe 660), propionate-oxidizing species, could only be detected in very low numbers of $<1 \%$ of total DAPI cell counts.

\section{Cytophaga/Flavobacterium Cluster}

Cytophaga/Flavobacterium related clone sequences were abundant in the clone libraries from Hydrate Ridge sediments. Therefore, the in situ abundance of this group was quantified by FISH as well. In the surface layers a fraction of $>1 \%$ could be affiliated with the Cytophaga/Flavobacterium cluster in the surface sediments at all sites (Table 3). Their abundance ranged from $5 \%$ in the uppermost layers to $<0.5 \%$ at $10.5 \mathrm{~cm}$ (Beggiatoa mat, station 105-1) and generally decreased with depth.

\section{Phylogenetic Diversity}

Three 16S rDNA clone libraries have been constructed to study the diversity of SRB and other bacteria in Hydrate Ridge sediments (Beggiatoa site, station 19-2). Different sediment depths $(0-1 \mathrm{~cm}, 2-4 \mathrm{~cm}$, and 8-9 cm) were selected according to biogeochemical gradients (concentrations of sulfate and sulfide, abundance of aggregates) for library construction. A total of $13116 \mathrm{~S}$ rDNA clones with the correct sized insert of $1.5 \mathrm{~kb}$ were screened by ARDRA and assigned to specific ARDRA patterns. There was no substantial difference in sequence diversity among the clone libraries from the different sediment horizons.

The 16S rDNA clone libraries obtained are phylogenetically diverse and include numerous cultivated as well as uncultivated bacterial lineages represented by 44 different ARDRA patterns (Table 4). SRB within the $\delta$-proteobacteria dominated the clone libraries from Hydrate Ridge sediments and constituted 53\% $(n=69)$ of all clones (Figure 6). Sequence similarity to cultivated species was in all cases lower than $95 \%$. However, similarity to sequences from uncultivated organisms was always high and often exceeded $98 \%$. Sequences related to Desulfosarcina species were the most abundant phylotype (14.5\%) with almost 95\% similarity. Together with environmental sequences from the Eel River Basin and the Guaymas Basin they form a clade specific for methane-rich sites with 97.0-99.0\% similarity to each other (group SEEP-SRB4). SEEP-SRB4 phylotypes were most often detected at the sediment surface and in $2-4 \mathrm{~cm}$ depth but not in the deep $(8-9 \mathrm{~cm})$ sediment layer.

Sequences related to the Desulfosarcina/Desulfococcus branch were the second most abundant phylotype recovered $(12.2 \%)$. This group comprises the complete-oxidizing 


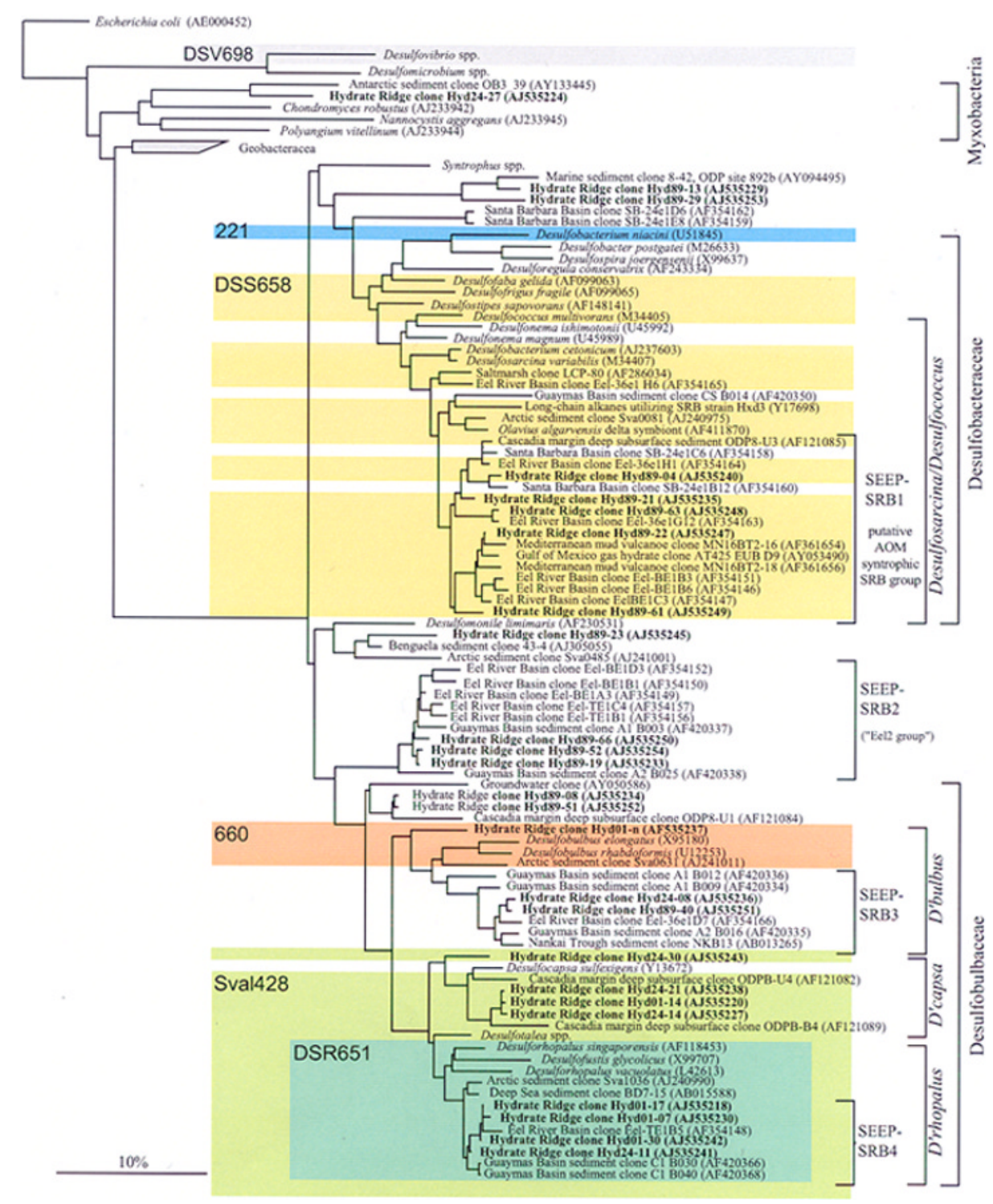

FIGURE 6 Phylogenetic tree showing the affiliations of Hydrate Ridge 16S rDNA clone sequences to selected reference sequences of the $\delta$-proteobacteria. The tree was calculated on a subset of 109 nearly full length sequences by maximum-likelihood analysis in combination with filters, which considered only $50 \%$ conserved regions of the $16 \mathrm{~S}$ rRNA of $\delta$-proteobacteria to exclude the influence of highly variable positions. A total of 1428 positions were used for analysis. Partial sequences (480-1000 bp: AF361656, AF361654, AJ305055, AF121085, AF121084, AF121082, and AF121089) have been inserted into the existing tree by parsimony criteria with global/local optimization, without allowing changes in the overall tree topology. Cloned 16S rDNA sequences from Hydrate Ridge sediments are in boldface type. Probe specificity shown with colored boxes. The bar represents $10 \%$ estimated phylogenetic divergence. 
genera Desulfosarcina spp., Desulfococcus spp., Desulfofrigus spp., Desulfofaba sp., and several other strains, which have not been further characterized yet. Hydrate Ridge sequences show a maximum similarity of $93.4 \%$ to cultivated species of this group. These and other environmental sequences form a seep-specific clade with $90.2-99.2 \%$ similarity to each other (group SEEP-SRB1).

Other SRB sequences from Hydrate Ridge group together with two additional seepspecific groups (SEEP-SRB2 and SEEP-SRB3) of environmental sequences from methanerich sites. SEEP-SRB2 comprises few sequences from Hydrate Ridge (2.3\%) and several sequences from the Eel River Basin and the Guaymas Basin. SEEP-SRB2 contains the uncultivated "Eel-2-group" from Eel River methane seep sediments (Orphan et al. 2001a), and has no close cultivated relatives ( $87 \%$ similarity). Sequence similarity to each other was 92.8-99.5\% (without the Guaymas Basin clone sequence A2 B025 even higher with 96.1-99.5\%). In all analysis, they formed an independent phylogenetic cluster among the $\delta$-proteobacteria that could not be assigned to cultivated genera.

SEEP-SRB3 is related to Desulfobulbus species (91\% similarity). Sequences of this group have $93.1-99.0 \%$ similarity to each other. Again, this group is formed by sequences from the Hydrate Ridge, the Eel River, and Guaymas Basin and also contains a sequence from deep sea sediments near Japan (Nankai Trough) (Li et al. 1999b), which is known to bear methane hydrate (Reed et al. 2002). The fourth group defined in this study named SEEP-SRB4 is related to Desulforhopalus species. Within this group sequence similarity is quite high with $97.0-99.9 \%$.

In addition to $\delta$-proteobacteria Hydrate Ridge libraries contained a large percentage of sequences affiliated with the Cytophaga/Flavobacterium phylum $(34 \%, n=45)$. Sequence similarity to cultivated species of the Cytophaga/Flavobacterium group was very low and in the range of 82 to $92 \%$. Two main groups (12 and 15\%) were detected, both most closely affiliated with Cytophaga marina and Flexibacter maritimus within the Flavobacteraceae. Many Hydrate Ridge sequences were closely related to sequence CS_B009 from the hydrothermally active Guaymas Basin sediment (99.6\% similarity) (Teske et al. 2002) although recovered from a geographically distant and cold site. These sequences were all retrieved from the $2-4 \mathrm{~cm}$ deep sediment layer.

Sequences related to $\gamma$-proteobacteria were detected in Hydrate Ridge sediments but comprised only a relatively small percentage (5\%). Clone sequences represented within this group included those highly affiliated with the aerobic methane-oxidizing bacterium Methylobacter luteus (94.4\%) and the sulfur-oxidizing bacteria Acidothiobacillus ferroxidans (94.9\%) and Leucothrix mucor (89.5\%).

One phylotype ( 4 clones) affiliated with $\varepsilon$-proteobacteria was found in the Hydrate Ridge sediment clone library from $2-4 \mathrm{~cm}$ depth. It branches with bacteria associated with the hydrothermal vent tubeworm Riftia pachyptila, with epibionts of the hydrothermal vent annelid Alvinella pompejana, and with environmental sequences from uncultivated $\delta$-proteobacteria found in cold seeps and the deep sea. Clones affiliated with other bacterial groups were retrieved in low numbers, including members of the phylum Firmicutes (Clostridiales, Haloanaerobiales) and the recently described Acidobacterium/Holophaga division. Sequences affiliated with $\alpha$ - and $\beta$-proteobacteria were not retrieved.

\section{Discussion}

\section{Bacterial Activity and Distribution above Hydrate}

There are two sources of energy and carbon at Hydrate Ridge nourishing the benthic microbial communities: (1) methane, which rises from below with venting fluids and decomposing 
hydrates, and (2) particulate organic matter (POC), which sinks to the seafloor from the productive ocean surface. Just as at any other continental margin the POC arriving at the seafloor of Hydrate Ridge fuels heterotrophic benthic communities, including aerobic microbes and metazoa as well as fermenting microbes and other anaerobic bacteria and archaea. From primary productivity in the water column it was estimated that about $2 \mathrm{mmol} \mathrm{C} \mathrm{m}^{-2} \mathrm{~d}^{-1}$ settle to the seafloor at a depth of $780 \mathrm{~m}$ (Sommer et al. 2002), a typical value for upper continental margins of productive oceans. It can be assumed that all investigated sites receive the same amount of POC. However, there is a considerable difference as to the availability of electron acceptors and electron donors at the different sites. At the reference station, nitrate penetrates down to $15 \mathrm{~cm}$ and methane and sulfide is very low or absent in the surface sediments (Bohrmann et al. 2000). In several of the reference cores, bivalves of the genus Acharax that harbor sulfide-oxidizing symbionts in their gills dwell deep into the sediments for access to sulfide. The reference site may obtain low fluxes of methane from greater depths or by advection from nearby vented sites; however, most of this methane is already consumed in the subsurface sediments below $15 \mathrm{~cm}$.

At the methane vented Calyptogena fields, nitrate penetrates only a few $\mathrm{cm}$ and sulfide increases considerably to values of $>10 \mathrm{mM}$ at $10 \mathrm{~cm}$ sediment depth (Torres et al. 2002). Beggiatoa mats receive the highest methane flux and are the most sulfidic, with $>10 \mathrm{mM}$ $\mathrm{H}_{2} \mathrm{~S}$ already in the top few $\mathrm{cm}$ (Torres et al. 2002). Accordingly, there are differences in the microbial abundance and activity of all three sites. Typical numbers of cells, production rates estimated from thymidine uptake into DNA, and extracellular hydrolytic activities for the degradation of POC were found in the surface sediments of the reference sites a few hundred meter away from the vented, hydrate-bearing sediments covered by Beggiatoa or Calytogena (for comparison see Boetius et al. 2000b). Similar production rates and hydrolytic enzyme activities as well as abundances of members of the Cytophaga/Flavobacterium cluster were found in the surface sediments of all sites, showing the activity of the microbial community in POC degradation. The hydrolytic enzyme activities found in the Hydrate Ridge sediments are comparable to those of other continental margin sediments at similar water depths (Boetius and Damm, 1998; Boetius et al. 2000b). In the subsurface sediments $(2-15 \mathrm{~cm})$, integrated production rates estimated from thymidine uptake were higher at the reference site than at the hydrate-bearing sites. The most abundant bacteria in hydrate-bearing sediments are SRB, which do not incorporate thymidine nor possess extracellular hydrolytic enzymes for the degradation of particulate matter (Widdel 1988). The only hydrolytic enzyme activity, which was significantly higher in hydrate-bearing, sulfidic sediments was that of sulfatase. Possibly, this enzyme is expressed by some bacteria to acquire sulfate from organic sources. Accordingly, the higher activity of sulfatase could be caused by the relatively high numbers of cells of the Cytophaga/Flavobacterium cluster found in the Beggiatoa surface layers (station 105-1, 185-1). Cytophaga spp. require sulfatases to cover its sulfur needs in the production of sulfonated sphingolipids (Godchaux and Leadbetter 1983).

Another substantial difference between the reference site and the hydrate-bearing sediments was total cell abundance, concerning single cells as well as cell aggregates. In hydrate-bearing sediments, total microbial biomass was much higher than at the reference site. Most of this "excess" microbial biomass was attributed to the methanotrophic community (Table 2) profiting from the much higher availability of methane compared to POC. Methane fluxes across the surface sediments exceed $100 \mathrm{mmol} \mathrm{C} \mathrm{m}^{-2} \mathrm{~d}^{-1}$ at vented sites (Torres et al. 2002; Boetius and Suess, submitted) compared to a POC input of $2 \mathrm{mmol}$ $\mathrm{C} \mathrm{m}^{-2} \mathrm{~d}^{-1}$. According to the difference in the source of energy, cell numbers and sulfate reduction rates are also two orders of magnitude higher at Beggiatoa mats and Calytogena fields compared to the reference site. Sulfate reduction rates are around $50 \mathrm{mmol} \mathrm{m}^{-2} \mathrm{~d}^{-1}$, matching very well the sulfide fluxes of 60 and $20 \mathrm{mmol} \mathrm{m}^{-2} \mathrm{~d}^{-1}$ beneath Beggiatoa mats 
and Calyptogena fields, respectively (Sahling et al. 2002). In contrast, sulfate reduction rates of $0.5 \mathrm{mmol} \mathrm{m}^{-2} \mathrm{~d}^{-1}$ at the reference site are relatively typical for a margin site at this water depth and can be explained solely by the POC input.

\section{Bacterial Diversity above Hydrate}

The bacterial diversity in clone libraries from Hydrate Ridge sediments was relatively high. In our study all identified clone sequences were $<95 \%$ similar to cultivated organisms. In contrast, in deep subsurface gas hydrate sediments from the same habitat (subduction zone in the Cascadia Margin, ODP leg 146, site 889/890) and in a massive gas hydrate from the Gulf of Mexico most of the bacterial clone sequences were $>95 \%$ similar to cultivated organisms (Lanoil et al. 2001; Marchesi et al. 2001). The investigated surface sediments from above outcropping hydrate are constantly vented by high concentrations of methane and replenished with electron acceptors from the oxic bottom waters by a variety of mixing processes (Sahling et al. 2002; Boetius and Suess, submitted). High biomass and diverse substrates are provided by the benthic macrofauna inhabiting the sediment surface (Sommer et al. 2002) and microbial activity is very high. This may explain the higher diversity found in hydrate-bearing surface sediments compared to deep subsurface zones and bulk hydrate.

The relatively high diversity in Hydrate Ridge sediments is in very good agreement with the findings from surface sediments of other methane-rich habitats. Teske et al. (2002) reported an extremely high bacterial diversity in hydrothermal sediments in the Guaymas Basin with 18 different phylogenetic groups. In hydrate-bearing sediments from Nankai Trough, Reed et al. (2002) reported a diverse microbial community with 22 unique sequences and 5 phylogenetic phyla; likewise, Lanoil et al. (2001) found 21 different phylotypes in sediments associated with hydrates from the Gulf of Mexico.

The phylogenetic analysis of Hydrate Ridge sequences resulted in many overlaps with sequences from other methane-rich sites. Gamma-, delta-, and epsilon-proteobacteria, members of the Cytophaga/Flavobacterium cluster, Actinobacteria, and Firmicutes are widespread in almost all methane-rich sediments investigated (e.g., Lanoil et al. 2001; Marchesi et al. 2001; Reed et al. 2002; Teske et al. 2002). However, within these phylogenetic groups no cluster seems to be endemic to methane-rich habitats (exception: $\delta$ proteobacteria). These groups have been typically recovered from marine sediments and are likely involved in the degradation of organic substances other than methane (e.g., Kato et al. 1997; Li et al. 1999a, 1999c; Ravenschlag et al. 1999; Rosselló-Mora et al. 1999; Urakawa et al. 1999; Bowman et al. 2000). Members of the Cytophaga/Flavobacterium cluster were also relatively abundant in clone libraries and were detected by FISH in the surface sediments. Cytophaga/Flavobacterium are known as ubiquitous degraders of polymers in marine habitats (Reichenbach 1991). This group is phylogenetically highly diverse and seems to play an ecological role as hydrolytic fermentative bacteria (Rosselló-Mora et al. 1999). Hence, members of this group were relatively abundant at all sites, but rather linked to the detritus food chain than to AOM. However, bacteria of this group could also use the high biomass of the DSS/ANME-2 aggregates.

One phylotype retrieved from Hydrate Ridge sediment clustered within the Myxobacteria. It was related to Chondromyces robustus and most closely affiliated with clone OB3_39 from Antarctic sediments (98.9\%). Known pure cultures of Myxobacteria are almost all predators of microorganisms (Reichenbach and Dworkin 1992). Therefore, they might play a role in the control of bacterial abundance.

Phylogenetic diversity within the $\delta$-proteobacterial SRB was very high and the Hydrate Ridge clone sequences could be affiliated with several genera (Figure 6). Most often these sequences originate from similar environments such as methane seeps from Eel River Basin 
(Orphan et al. 2001a), the Santa Barbara Basin (Orphan et al. 2001a), the Guaymas Basin (Teske et al. 2002), and the Gulf of Mexico (Lanoil et al. 2001). Four distinct clusters of highly related sequences could be detected that appear to be specifically associated with methane seep communities (see discussion below). In contrast to the relatively high bacterial diversity, the archaeal diversity in methane-rich environments has always been described as quite low (Bidle et al. 1999; Hinrichs et al. 1999; Lanoil et al. 2001; Marchesi et al. 2001; Orphan et al. 2001a; Reed et al. 2002; Teske et al. 2002; Thomsen et al. 2001). Most often only two phylogenetic groups, ANME-1 and ANME-2, were retrieved from the sediments. However, the phylogenetic diversity of archaea capable of anaerobic oxidation of methane is still under investigation, and more groups may be found when further clone libraries are examined.

Another SRB type of interesting function in the highly sulfidic sediments of Hydrate Ridge are those related to Desulfocapsa sulfexigens, a bacterium capable of inorganic sulfur disproportionation (Finster et al. 1998). Sequences related to Desulfocapsa were the third most abundant SRB phylotype recovered (11.4\%) and closely affiliated with sequences from Cascadia margin deep subsurface sediments (Bidle et al. 1999). These bacteria may play an important role in the very rapid sulfur cycling at seeps.

\section{SRB Involved in AOM-A Single Specialist or Diversity of Different SRB?}

Previous studies have shown that both archaeal ANME groups and members of the Desulfosarcina/Desulfococcus branch co-occur in methane-rich sediments (Boetius et al. 2000a; Orphan et al. 2001b, 2002; Michaelis et al. 2002). Studies using FISH and secondary ion mass spectrometry analysis provided direct evidence for their involvement in AOM (Orphan et al. 2001b, 2002). As in most syntrophic consortia, this process does not seem to obligatorily require the physical attachment of SRB to methanogenic archaea. Orphan et al. showed that monospecific single archaeal cells and cell aggregates were depleted in $\delta^{13} \mathrm{C}$ indicative of methanotrophy, as were multispecific consortia (Orphan et al. 2002). An important open question for understanding the process of AOM still remaining is whether all AOM consortia contain a highly specialized SRB partner (Desulfosarcina/Desulfococcus cells) or whether the role of $\mathrm{H}_{2}$ and/or acetate scavenging syntrophic partners can be filled by a diversity of different SRB, including free-living single cells.

Not only the archaeal groups ANME1 and ANME2 can be detected exclusively in methane-rich anoxic habitats (Hinrichs et al. 1999; Lanoil et al. 2001; Orphan et al. 2001a; Thomsen et al. 2001; Heijs et al. 2002; Teske et al. 2002), but there are also several groups of SRB endemic to seep sites. Four such distinct clusters of highly related sequences were detected: Besides Hydrate Ridge sequences these newly defined $\delta$-proteobacterial groups (SEEP-SRB 1 to SEEP-SRB4) comprise multiple sequences retrieved from various sediment samples from different habitats: the Gulf of Mexico gas hydrates (Lanoil et al. 2001), Eel River and Santa Barbara Basin methane seeps (Orphan et al. 2001a), Mediterranean carbonate crusts from mud volcano sites (Heijs et al. 2002), Cascadia margin deep subsurface sediments (Bidle et al. 1999), and surface sediments at hydrothermal vents in the Guaymas Basin (Teske et al. 2002). Sequences within this Desulfosarcina/Desulfococcus branch (defined as SEEP-SRB1) were very abundant in the clone library in Hydrate Ridge sediments. This group represents the AOM syntrophic SRB group, which lives together with ANME-2 cells in a syntrophic consortium, and that also occurs as partner of ANME-1 (Michaelis et al. 2002). The SRB of this group were the most abundant bacteria at Hydrate Ridge with total numbers of aggregated cells of more than $10^{10} \mathrm{~cm}^{-3}$ in hydrate-bearing sediments (Table 2). Furthermore, they were also the most abundant single sulfate reducers in Hydrate Ridge sediment samples and accounted for $18 \%$ up to $100 \%$ of total detected 
SRB (Table 3). In contrast, single ANME-2 have barely been detected ( $<1 \%$ of total single cells). In addition to being a common component of methane-rich habitats, members of the Desulfosarcina/Desulfococcus branch have also been shown to be very abundant in other marine sediments (Rooney-Varga et al. 1997; Edgcomb et al. 1999; Sahm et al. 1999a; Ravenschlag et al. 2000) and made up to $73 \%$ of total SRB in Arctic sediments. Also, they occur as symbionts in a marine oligochaete (Dubilier et al. 2001). The high abundance in different habitats also underlines that members of this group seem to be fit to survive under various conditions. Members of the Desulfosarcina/Desulfococcus branch include nutritionally versatile SRB that oxidize organic compounds including acetate completely to $\mathrm{CO}_{2}$, and several species can grow autotrophically with $\mathrm{CO}_{2}, \mathrm{H}_{2}$, and sulfate (Widdel and Hansen 1992b). The low sequence similarity of group SEEP-SRB1 to cultivated species (max. 93\%) and within the group itself (90.2-99.2\%) points to new, still uncharacterized species or even new genera with unknown physiological properties. This is supported by data from an accompanying study by Elvert et al. (2003, this issue) who found an enrichment of unusual fatty acids in Hydrate Ridge sediments $\left(\mathrm{C}_{16: 1 \omega 5 \mathrm{c}}, \mathrm{C}_{17: 1 \omega 6 \mathrm{c}}\right.$, and cy $\left.\mathrm{C}_{17: 0 \omega 5,6}\right)$ which have the lowest $\delta^{13} \mathrm{C}$ values throught the sediment core. This specific fatty acid pattern was defined as a stable chemotaxonomic marker for SRB of the Desulfosarcina/Desulfococcus branch represented in ANME-2/DSS aggregates (for detailed discussion see Elvert et al. 2003, this issue).

In this study we defined three more SRB groups (i.e., SEEP-SRB2 to SRB4) that are currently associated exclusively with methane-rich, anoxic sites. The presence of these groups suggests a direct or indirect involvement in AOM by using intermediates or metabolic end products of this process, or maybe specific organic substrates provided by seep-characteristic macrofaunal communities around vent sites (e.g., mats of filamentous sulfur-oxidizing bacteria Beggiatoa spp., vesicomyid clams Calyptogena spp., solemyid bivalve molluscs of genus Acharax [Levin et al. 2000; Olu et al. 1997; Sahling et al. 2002]). However, Nauhaus et al. (2002) tested in vitro if the SRB community (including members of the Desulfosarcina/Desulfococcus branch) of hydrate-bearing sediments from Hydrate Ridge can be decoupled from methane oxidation by adding various potential SRB substrates (or AOM intermediates). Sulfate reduction was fueled by methane more than by any other electron donor, pointing to a direct link between methane oxidation and sulfate reduction.

The methane seep-specific groups SEEP-SRB3 and SEEP-SRB4 were located within the Desulfobulbaceaea and related to the genera Desulfobulbus and Desulforhopalus, respectively. SRB detected by probe DSR651, specific for Desulforhopalus relatives and SEEP-SRB4, were the most abundant group in the clone library and the second abundant group as detected by FISH in situ. However, their numbers of up to $1.7 \times 10^{8}$ cells per $\mathrm{ml}$ in the uppermost layer were two orders of magnitude lower than those of the SRB of the Desulfosarcina/Desulfococcus branch represented in ANME-2/DSS aggregates. This once again shows the limitation in making quantitative assumptions based on clone frequencies.

SEEP-SRB2 (unclear phylogenetic affiliation) and SEEP-SRB3 (related to Desulfobulbus species) were not targeted by the set of probes used in this study. New probes have to be developed to quantify the abundance and will clarify the importance of these groups for AOM sites. A first indication of AOM-relevance of these groups was shown by very negative $\delta^{13} \mathrm{C}$-values of specific fatty acids extracted from Hydrate Ridge sediments. Elvert et al. (2003, this issue) reported a significant ${ }^{12} \mathrm{C}$-enriched carbon isotope value $(-80 \%$ in 0-19 cm depth in average) for the membrane fatty acid $\mathrm{C}_{17: 1 \omega 6 \mathrm{c}}$, which is specific for Desulfobulbus species (but also found in Desulforhopalus species). In addition the dominant fatty acid $\mathrm{C}_{16: 1 \omega 5 \mathrm{c}}$ in Hydrate Ridge sediments, which were formerly assigned to organisms within the Desulforhopalus/Desulfococcus branch $\left({ }^{13} \mathrm{C}:-90 \%\right)$, has also been detected 
in Desulfobulbus and Desulfosarcina. These findings support the hypothesis that both Desulforhopalus and Desulfobulbus related AOM-specific groups (SEEP-SRB34) might be involved in AOM besides members of the Desulfosarcina/Desulfococcus branch. Extremely ${ }^{13} \mathrm{C}$-depleted bacterial lipids recovered from other methane-rich sites were also structurally diverse and likely originated from multiple bacterial sources (Pancost et al. 2000; Orphan et al. 2001a; Thiel et al. 2001; Zhang et al. 2002). It may be that these bacterial groups form partnerships with other methane-oxidizing archaea unknown at present. In Hydrate Ridge sediments, however, we did not find evidence for other bacterial associations than Desulfosarcina/Desulfococcus cells with the methane-oxidizing archaeal ANME-2 group, or for other cell associations. In contrast, in Eel River Basin sediment samples Orphan and coworkers found ANME-2 aggregates, which comprised bacterial partners other than the Desulfosarcina related species (Orphan et al. 2002). Furthermore, Orphan et al. (2001a) could define several "Eel groups" (Eel 1, Eel 3) which were missing at Hydrate Ridge.

\section{Conclusions}

This is the first quantitative analysis of bacterial diversity, distribution, and activity of a cold seep environment. Typical for continental margin sediments of productive ocean regions, an active and diverse bacterial community involved in the degradation of organic matter was found in the surface sediments. However, highest biomasses, activities, and phylogenetic diversity occurred at the methane-vented sediments above surficial gas hydrates. The dominant process in these sediments is the anaerobic oxidation of methane via sulfate reduction. A high diversity of sulfate-reducing bacteria was found in the gas hydrate-bearing sediments and four seep-specific phylogenetic clusters were recognized. Members of the Desulfosarcina/Desulfococcus group represent the dominant cluster of SRB, and are directly involved in anaerobic oxidation of methane as part of a syntrophic consortium. Most of the bacterial diversity comprises seep-endemic clades, which share only low similarities with previously cultured bacteria.

\section{References}

Amann RI, Krumholz L, Stahl DA. 1990. Fluorescent-oligonucleotide probing of whole cells for determinative, phylogenetic, and environmental studies in microbiology. J Bacteriol 172:762770 .

Bidle KA, Kastner M, Bartlett DH. 1999. A phylogenetic analysis of microbial communities associated with methane hydrate containing marine fluids and sediments in the Cascadia margin (ODP8 site 892B). FEMS Microbiol Lett 177:101-108.

Boetius A, Damm E. 1998. Benthic oxygen uptake, hydrolytic potentials and microbial biomass at the Arctic continental slope. Deep-Sea Res I 45:239-275.

Boetius A, Ferdelmann T, Lochte K. 2000b. Bacterial activity in sediments of the deep Arabian Sea in relation to vertical flux. Deep Sea Res II 47:2835-2875.

Boetius A, Ravenschlag K, Schubert C, Rickert D, Widdel F, Gieseke A, Amann R, Jørgensen BB, Witte U, Pfannkuche O. 2000a. A marine microbial consortium apparently mediating anaerobic oxidation of methane. Nature 407:623-626.

Boetius A, Suess E, submitted. Hydrate Ridge: a natural laboratory for the study of microbial life fueled by methane from near-surface gas hydrates. Chem Geol.

Bohrmann G, Linke P, Suess E, Pfannkuche O, 2000. R.V. SONNE cruise Report SO143: TECFLUX-I (June 29-September 6, 1999; Honolulu-Astoria-San Diego). GEOMAR Report 93:217.

Børsheim KY, Bratbak G, Heldal M. 1991. Enumeration and biomass estimation of planktonic bacteria and viruses by transmission electron microscopy. Appl Environ Microbiol 56:352-356. 
Bowman JP, Rea SM, McCammon SA, McMeekin TA. 2000. Diversity and community structure within anoxic sediment from marine salinity meromyctic lakes and a coastal meromictic marine basin, Vestfold Hills, eastern Antarctica. Environ Microbiol 2:227-237.

Daims H, Brühl A, Amann R, Schleifer KH, Wagner, M. 1999. The domain-specific probe EUB338 is insufficient for the detection of all bacteria: development and evaluation of a more comprehensive probe set. Syst Appl Microbiol 22:434-444.

Devereux R, Kane MD, Winfrey J, Stahl DA. 1992. Genus- and group-specific hybridization probes for determinative and environmental studies of sulfate-reducing bacteria. Syst Appl Microbiol 15:601-609.

Dubilier N, Mülders C, Ferdelman T, de Beer D, Pernthaler A, Klein M, Wagner M, Erséus C, Thiermann F, Krieger J, Giere O, Amann R. 2001. Endosymbiotic sulphate-reducing and sulphideoxidizing bacteria in an oligochaete worm. Nature 411:298-302.

Edgcomb VP, McDonald JH, Devereux R, Smith DW. 1999. Estimation of bacterial cell numbers in humic acid-rich salt marsh sediments with probes directed to $16 \mathrm{~S}$ ribosomal DNA. Appl Environ Microbiol 65:1516-1523.

Elvert M, Boetius A, Knittel K, Jørgensen BB. 2003. Characterization of specific membrane fatty acids as chemotaxonomic markers for sulfate-reducing bacteria involved in anaerobic oxidation of methane. Geomicrobiol J 20:403-419.

Findlay S. 1993. Thymidine incorporation into DNA as an estimate of sediment bacterial production. In: PF Kemp, editor. Handbook of Methods in Aquatic Microbial Ecology. Florida: Lewis Publishers. p 505-508.

Finster K, Liesack W, Thamdrup B. 1998. Elemental sulfur and thiosulfate disproportionation by Desulfocapsa sulfoexigens sp. nov., a new anaerobic bacterium isolated from marine surface sediments. Appl Environ Microbiol 64:119-125.

Fossing H, Jørgensen BB. 1989. Measurements of bacterial sulfate reduction in sediments: evaluation of a single-step chromium reduction method. Biogeochemistry 8:205-222.

Godchaux W 3rd, Leadbetter ER. 1983. Unusual sulfonolipids are characteristic of the CytophagaFlexibacter group. J Bacteriol 153:1238-1246.

Hansen LB, Finster K, Fossing H, Iversen N. 1998. Anaerobic methane oxidation in sulfate depleted sediments: effects of sulfate and molybdate additions. Aquat Microb Ecol 14:195-204.

Heijs SK, Aloisi G, Bouloubassi I, Forney LJ, Pancost RD, Pierre C, Sinninghe Damste JS, Gottschal JC. 2002. Microbial community structure of three deep sea carbonate crusts: novel Archaea involved in anaerobic methane oxidation? Database release: AF361645-AF361680.

Hinrichs KU, Hayes JM, Sylva SP, Brewer PG, DeLong EF. 1999. Methane-consuming archaebacteria in marine sediments. Nature 398:802-805.

Hinrichs K-U, Boetius A. 2002. The anaerobic oxidation of methane: new insights in microbial ecology and biogeochemistry. In: Wefer G, Billett D, Hebbeln D, Jørgensen BB, Schlüter M, T. VW, editors. Ocean Margin Systems. Berlin Heidelberg: Springer-Verlag. p 457-477.

Hoehler TM, Alperin MJ, Albert DB, Martens CS. 1994. Field and laboratory studies of methane oxidation in an anoxic marine sediment: evidence for a methanogen-sulfate reducer consortium. Glob Biogeochem Cycles 8:451-463.

Kane MD, Poulsen LK, Stahl DA. 1993. Monitoring the enrichment and isolation of sulfate-reducing bacteria by using oligonucleotide hybridization probes designed from environmentally derived 16S rRNA sequences. Appl Environ Microbiol 59:682-686.

Kato C, Li L, Tamaoka J, Horikoshi K. 1997. Molecular analyses of the sediment of the 11000-m deep Mariana Trench. Extremophiles 1:117-123.

Lanoil BD, Sassen R, La Duc MT, Sweet ST, Nealson KH. 2001. Bacteria and Archaea physically associated with Gulf of Mexico Gas Hydrates. Appl Environ Microbiol 67:5143-5153.

Levin LA, James DW, Martin CM, Rathburn AE, Harris LH, Michener RH. 2000. Do methane seeps support distinct macrofaunal assemblages? Observations on community structure and nutrition from the northern California slope and shelf. Mar Ecol Prog Ser 208:21-39.

Li L, Kato C, Horikoshi K. 1999a. Bacterial diversity in deep-sea sediments from different depths. Biodivers Conserv 8:659-677.

Li L, Guezennec J, Nichols P, Henry P, Yanagibayashi M, Kato C. 1999b. Microbial diversity in Nankai Trough sediments at a depth of $3843 \mathrm{~m}$. J Oceanogr 55:635-642. 
Li L, Kato C, Horikoshi K. 1999c. Microbial diversity in sediments collected from the deepest coldseep area, the Japan trench. Mar Biotechnol 1:391-400.

Linke P, Suess E. 2001. R.V. SONNE cruise Report SO148 TECFLUX-II-2000 (Victoria-Victoria; July 20-August 12, 2000). GEOMAR Report 98:122.

Manz W, Amann R, Ludwig W, Vancanneyt M, Schleifer K-H. 1996. Application of a suite of 16S rRNA-specific oligonucleotide probes designed to investigate bacteria of the phylum cytophagaflavobacter-bacteroides in the natural environment. Microbiology 142:1097-1106.

Manz W, Eisenbrecher M, Neu TR, Szewzyk U. 1998. Abundance and spatial organization of gram negative sulfate-reducing bacteria in activated sludge investigated by in situ probing with specific 16S rRNA targeted oligonucleotides. FEMS Microbiol Ecol 25:43-61.

Marchesi JR, Weightman AJ, Cragg BA, Parkes RJ, Fry JC. 2001. Methanogen and bacterial diversity and distribution in deep gas hydrate sediments from the Cascadia Margin as revealed by $16 \mathrm{~S}$ rRNA molecular analysis. FEMS Microbiol Ecol 34:221-228.

Meyer-Reil, LA 1983. Benthic response to sedimentation events during autumn to spring at a shallow water station in the western Kiel Bight. Mar Biol 77:247-256.

Michaelis W, Seifert R, Nauhaus K, Treude T, Thiel V, Blumenberg M, Knittel K, Gieseke A, Peterkencht K, Pape T, Boetius A, Amann R, Jørgensen BB, Widdel F, Peckmann J, Pimenov NV, Gulin MB. 2002. Microbial reefs in the Black Sea fueled by anaerobic oxidation of methane. Science 297:1013-1015.

Muyzer G, Teske A, Wirsen CO, Jannasch HW. 1995. Phylogenetic relationships of Thiomicrospira species and their identification in deep-sea hydrothermal vent samples by denaturing gradient gel electrophoresis of 16S rDNA fragments. Arch Microbiol 164:165-172.

Nauhaus K, Boetius A, Krüger M, Widdel F. 2002. In vitro demonstration of anaerobic oxidation of methane coupled to sulphate reduction in sediment from a marine gas hydrate area. Environ Microbiol 4:296-305.

Olu K, Lance S, Sibuet M, Henry P, Fiala-Médioni A, Dinet A. 1997. Cold seep communities as indicators of fluid expulsion patterns through mud vulcanoes seaward of the Barbardos accretionary prisms. Deep-Sea Res 44:811-841.

Orphan VJ, Hinrichs K-U, Ussler III W, Paull CK, Taylor LT, Sylva SP, Hayes JM, DeLong EF. 2001a. Comparative analysis of methane-oxidizing archaea and sulfate-reducing bacteria in anoxic marine sediments. Appl Environ Microbiol 67:1922-1934.

Orphan VJ, House CH, Hinrichs K-U, McKeegan KD, DeLong EF. 2001b. Methane-consuming archaea revealed by directly coupled isotopic and phylogenetic analysis. Science 293:484-487.

Orphan VJ, House CH, Hinrichs K-U, McKeegan KD, DeLong EF. 2002. Multiple archaeal groups mediate methane oxidation in anoxic cold seep sediments. Proc Natl Acad Sci 99:7663-7668.

Pace NR. 1997. A molecular view of microbial diversity and the biosphere. Science 276:734-740.

Pancost RD, Sinninghe Damsté SJ, de Lint S, van der Maarel MJEC, Gottschal JC, the Medinaut Shipboard Scientific Party. 2000. Biomarker evidence for widespread anaerobic methane oxidation in Mediterranean sediments by a consortium of methanogenic archaea and bacteria. Appl Environ Microbiol 66:1126-1132.

Ravenschlag K, Sahm K, Pernthaler J, Amann R. 1999. High bacterial diversity in permanently cold marine sediments. Appl Environ Microbiol 65:3982-3989.

Ravenschlag K, Sahm K, Knoblauch C, Jørgensen BB, Amann R. 2000. Community structure, cellular rRNA content and activity of sulfate-reducing bacteria in marine Arctic sediments. Appl Environ Microbiol 66:3592-3602.

Ravenschlag K, Sahm K, Amann R. 2001. Quantitative molecular analysis of the microbial community in marine Arctic sediments (Svalbard). Appl Environ Microbiol 67:387-395.

Reeburgh WS. 1996. "Soft spots" in the global methane budget. In: Lidstrom ME, Tabita FR, editors. Microbial Growth on $\mathrm{C}_{1}$ Compounds. Dordrecht: Kluwer Academic Publishers. p 334-342.

Reed DW, Fujita Y, Delwiche ME, Blackwelder DB, Sheridan PP, Uchida T, Colwell FS. 2002. Microbial communities from methane hydrate-bearing deep marine sediments in a forearc basin. Appl Environ Microbiol 68:3759-3770.

Reichenbach H. 1991. The order Cytophagales. In: Balows A, Trüper HG, Dworkin M, Harder W, Schleifer K-H, editors. The Prokaryotes. Berlin, Germany: Springer-Verlag. p 3631-3675. 
Reichenbach H, Dworkin M. 1992. The myxobacteria. In: Balows A, Trüper HG, Dworkin M, Harder W, Schleifer K-H, editors. The Prokaryotes. New York: Springer-Verlag. p 3416-3487.

Rooney-Varga JN, Devereux R, Evans RS, Hines ME. 1997. Seasonal changes in the relative abundance of uncultivated sulfate-reducing bacteria in a salt marsh sediment and in the rhizosphere of Spartina alterniflora. Appl Environ Microbiol 63:3895-3901.

Rosselló-Mora R, Thamdrup B, Schaefer H, Weller R, Amann R. 1999. The response of the microbial community of marine sediments to organic carbon input under anaerobic conditions. Syst Appl Microbiol 22:237-248.

Sahling H, Rickert D, Lee RW, Linke P, Suess E. 2002. Macrofaunal community structure and sulfide flux at gas hydrate deposits from the Cascadia convergent margin, NE Pacific. Mar Ecol Prog Ser 231:121-138.

Sahm K, MacGregor BJ, Jørgensen BB, Stahl DA. 1999a. Sulfate reduction and vertical distribution of sulfate-reducing bacteria quantified by rRNA slot-blot hybridization in a coastal marine sediment. Environ Microbiol 1:65-74.

Sahm K, Knoblauch C, Amann R. 1999b. Phylogenetic affiliation and quantification of psychrophilic sulfate-reducing isolates in marine arctic sediments. Appl Environ Microbiol 65:3976-3981.

Snaidr J, Amann R, Huber I, Ludwig W, Schleifer KH. 1997. Phylogenetic analysis and in situ identification of bacteria in activated sludge. Appl Environ Microbiol 63:2884-2896.

Sommer S, Pfannkuche O, Rickert D, Kähler A, 2002. Surficial marine gas hydrates and their ecological implications for the small-sized benthic biota at the Hydrate Ridge. Mar Ecol Prog Ser 243:25-38.

Strunk O, Gross O, Reichel B, May M, Hermann S, Stuckman N, Nonhoff B, Lenke M, Ginhart A, Vilbig A, Ludwig T, Bode A, Schleifer K-H, Ludwig W. 1998. ARB: a software environment for sequence data. http://www.mikro.biologie.tumuenchen.de. Department of Microbiology Technische Universitat Munchen, Munich, Germany.

Suess E, Torres ME, Bohrmann G, Collier RW, Greinert J, Linke P, Rehder G, Trehu A, Wallmann K, Winckler G, Zuleger E. 1999. Gas hydrate destabilization: enhanced dewatering, benthic material turnover and large methane plumes at the Cascadia convergent margin. Earth Planet Sci Lett 170:1-15.

Suess E, Bohrmann G, Rickert D, Kuhs W, Torres ME, Trehu A, Linke P, 2002. Properties and fabric of near-surface methane hydrates at Hydrate Ridge, Cascadia margin. Proc 4th Intl Conf Gas Hydrates, Yokohama: 740-744.

Teske A, Hinrichs K-U, Edgcomb V, de Vera Gomez A, Kysela D, Sylva SP, Sogin ML, Jannasch HW. 2002. Microbial diversity of hydrothermal sediments in the Guaymas Basin: evidence for anaerobic methanotrophic communities. Appl Environ Microbiol 68:1994-2007.

Thiel V, Peckmann J, Richnow HH, Luth U, Reitner J, Michaelis W. 2001. Molecular signals for anaerobic methane oxidation in Black Sea seep carbonates and a microbial mat. Mar Chem 73:97-112.

Thomsen TR, Finster K, Ramsing NB. 2001. Biogeochemical and molecular signatures of anaerobic methane oxidation in a marine sediment. Appl Environ Microbiol 67:1646-1656.

Torres ME, McManus J, Hammond D, de Angelis MA, Heeschen K, Colbert S, Tryon MD, Brown KM, Suess E. 2002. Fluid and chemical fluxes in and out of sediments hosting methane hydrate deposits on Hydrate Ridge, OR, I: Hydrological Provinces, Earth Planet Sci Lett 201:525540.

Treude T, Boctius A, Knittel K, Wallmann K, Jørgensen BB. Anaerobic oxidation of methane above gas hydrates (Hydrate Ridge, OR). submitted. Aquat Microbiol Ecol.

Tryon MD, Brown KM, Torres ME. 2002. Fluid and chemical flux in and out of sediments hosting methane hydrate deposits on Hydrate Ridge, OR, II: Hydrological processes. Earth Plan Sci Lett 201:541-557.

Urakawa H, Kita-Tsukamota K, Ohwada K. 1999. Microbial diversity in marine sediments from Sagami Bay and Tokyo Bay, Japan, as determined by 16S rRNA gene analysis. Microbiology 145:3305-3315.

Valentine DL, Reeburgh WS. 2000. New perspectives on anaerobic methane oxidation. Environ Microbiol 2:477-484. 
Wallner G, Amann R, Beisker W. 1993. Optimizing fluorescent in situ hybridization with rRNAtargeted oligonucleotide probes for flow cytometric identification of microorganism. Cytometry 14:136-143.

Widdel F, 1988. Microbiology and ecology of sulfate- and sulfur reducing bacteria. In: A. Zehnder, editor. Biology of Anaerobic Microorganisms. New York: Wiley. p 469-585.

Widdel F, Bak F. 1992a. Gram-negative mesophilic sulfate-reducing bacteria. In: Balows A, Trüper HG, Dworkin M, Harder W, Schleifer K-H, editors. The Prokaryotes. 2 ed. New York: SpringerVerlag, p 3352-3378.

Widdel F, Hansen T. 1992b. The dissimilatory sulfate- and sulfur-reducing bacteria. In: Balows A, Trüper HG, Dworkin M, Harder W, Schleifer K-H, editors. The Prokaryotes. 2 ed. New York: Springer-Verlag. p 583-624.

Zhang CLYL, Wall JD, Larsen L, Sassen R, Huang Y, Wang Y, Peacock A, White DC, Horita J, Cole DR. 2002. Lipid and carbon isotopic evidence of methane-oxidizing and sulfate-reducing bacteria in association with gas hydrates from the Gulf of Mexico. Geology 30:239-242.

Zhou J, Brunns MA, Tiedje JM. 1996. DNA recovery from soils of diverse composition. Appl Environ Microbiol 62:316-322. 